Central Washington University

ScholarWorks@CWU

$9-1-2012$

"Savages" in the Service of Empire: Native American Soldiers in Gorham's Rangers, 1744-1762

Brian D. Carroll

Follow this and additional works at: https://digitalcommons.cwu.edu/cahfac_history

Part of the Indigenous Studies Commons, and the United States History Commons 


\title{
"Savages" in the Service of Empire: Native American Soldiers in Gorham's Rangers, $1744-1762$
}

BRIAN D. CARROLL

\begin{abstract}
C ORHAM'S RANGERS, formed in 1744 as an auxiliary $G$ unit of the Massachusetts provincial army, was an amphibious strike force that patrolled the coasts, inlets, bays, and rivers of the Canadian Maritimes in modified whaleboats. ${ }^{1}$ Initially manned by Native Americans from southeastern Massachusetts and commanded by British colonial officers, by its final deployments in the early 176os, Gorham's Rangers had become a unit of mostly Anglo-Americans and recent Scots and Irish immigrants who, nonetheless, continued to employ the tactics the unit's original Indian members had pioneered. For Indian members of the company the cost had been dear; combat fatalities, disease, debilitating wounds and injuries, and years of brutal captivity in French or Indian communities in Canada were common fates.

Robert Rogers is widely credited with instituting the American ranger tradition and, thus, with establishing, during the French and Indian War (1754-63), a uniquely American style of warfare based in Indian strategies. Dating that innovation to
\end{abstract}

I express my sincerest gratitude to Wayne E. Lee, Geoffrey Plank, and Andrew Pierce for sharing citations, sources, or copies of unpublished work. Also many thanks to Marna Carroll, Harald E. L. Prins, Wayne E. Lee, Daniel R. Mandell, Erik Seeman, William P. Tatum III, Jean-François Lozier, and Daniel Herman, all of whom commented on drafts or were willing to discuss aspects of the article with me.

${ }^{1}$ Earlier units commanded by Benjamin Church had done likewise in Maine in the 169os and early 170os. See my "From Warrior to Soldier: New England Indians in the Colonial Military, 1676-1763" (Ph.D diss., University of Connecticut, 2009), pp. $157-93$.

The New England Quarterly, vol. LXXXV, no. 3 (September 2012). (C) 2012 by The New England Quarterly. All rights reserved. 
an earlier period, some scholars assert that Rogers was merely heir apparent to men such as Benjamin Church, who secured an

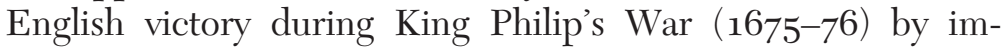
plementing Indian martial practices. Still others argue that the American way of war emerged from a grand, postcontact dialogical process that significantly altered military methods among Native Americans and Anglo-Americans alike. ${ }^{2}$ Gorham's Rangers, arguably the true descendants of Church's early companies as well as the immediate antecedents to and model for Rogers's Rangers, offers an opportunity to assess these reigning assumptions and to examine the evolution of American warfare at the edges of empire.

Church and Rogers are well known largely because each published a detailed (and self-serving) memoir chronicling his accomplishments; ${ }^{3}$ John Gorham III (1709-51) and his younger

\footnotetext{
${ }^{2}$ Wayne Lee reviews the literature in "Early American Ways of War: A New Reconnaissance, 1600-1815," Historical Journal 44 (2001): 269-89, and in "Mind and Matter-Cultural Analysis in American Military History: A Look at the State of the Field," Journal of American History 93 (2007): 1116-42. John Grenier's assessment of the literature is much the same in The First Way of War: American War Making on the Frontier, 1607-1814 (New York: Cambridge University Press, 2005), pp. 6-10. Russell Weigley, in his The American Way of War: A History of United States Military Strategy and Policy (Bloomington: Indiana University Press, 1977), argues for a uniquely American way of war characterized not by "irregular" or "regular" tactics but by wars of attrition or wars of annihilation. Armstrong Starkey, who posits in his European and Native American Warfare (Norman: Oklahoma University Press, 1998) that Europeans were never terribly successful at adopting Native American frontier warfare (guerilla tactics) until 1814, essentially agrees with Guy Chet, who claims, in his Conquering the American Wilderness: The Triumph of European Warfare in the Colonial Northeast (Amherst: University of Massachusetts Press, 2003), that European linear tactics remained dominant throughout the colonial period. Refuting Starkey and Chet, Grenier insists that the early American way of war was characterized by intense intercultural violence, irregular frontier warfare, and campaigns of total war that were aimed at killing noncombatants and destroying Indian villages and resources. In "Mind and Matter," Lee concurs: "Norms of warfare against Indians included scalping, village destruction, food destruction, indiscriminate killing of women and children (or even allied Indians), enslavement, and very likely rape" ("Mind and Matter," p. 1128); Adam J. Hirsch, in "The Collision of Military Cultures in Seventeenth-Century New England," Journal of American History 74 (1988): 1187-212, and Patrick M. Malone, in The Skulking Way of War: Technology and Tactics among the New England Indians (New York: Madison Books, 1991), pioneered the "collision of military cultures" thesis, which maintains that Europeans and Native Americans adjusted to intercultural violence and adopted total war practices.

${ }^{3}$ Church's memoir was compiled toward the end of his life with the assistance of his son. Thomas Church, Entertaining Passages Relating to Philip's War . . Also
} 
brother Joseph (1724-90) left no such record. Still, as will be explored and analyzed below, widely scattered documents relating to the activities of Gorham's Rangers in the northeastern borderlands and to the company's origins, organization, and composition amply demonstrate the critical role the unit's Native American soldiers played in forging the "irregular" or guerilla tactics most often attributed to Church and to Rogers. ${ }^{4}$

\section{"Indians and Other Men Fit for Ranging"}

As early as King Philip's War, the colonies of Connecticut and Massachusetts began incorporating settlement or reservation Indians, in this case Mohegan and Pequot tribal units, into their armed forces while also forming special companies of Nipmuc and Wampanoag warriors led by English commanders. Over the next sixty-five years, as the colonies expanded this practice, Native Americans assumed an increasingly important role in New England's military endeavors. Why Indian warriors would have chosen to fight for their conquerors and oppressors is a complex phenomenon that speaks to the conditions they faced in the aftermath of King Philip's demise.

English victory in that conflict radically affected the lives of all Native Americans in southern New England. First, they lost their political independence; then, as colonial settlements encroached on their lands, they suffered a shrinking resource base and ecological change. In time, they were relegated to dozens of small reservations peppered throughout the region, or they eked out a living in enclaves on the margins of colonial

\footnotetext{
of Expeditions More lately made Against the Common Enemy, and Indian Rebels, in the Eastern Parts of New England. . . (Boston: Benjamin Green, 1716); Journals of Major Robert Rogers: Containing An Account of several Excursions he made under the Generals who commanded upon the Continent of North America . . (London, 1765).

${ }^{4}$ Papers relating to Gorham's company are in Quebec, Ottawa, and Halifax in Canada and Massachusetts, Pennsylvania, New York, Michigan, and California in the United States. The best history of Gorham's Rangers to date is in John Grenier's The Far Reaches of Empire: War in Nova Scotia, 1710-1760 (Norman: University of Oklahoma Press, 2008), the strength of which lies in Grenier's detailed chronicling of the company's operational history. Grenier also briefly examined Gorham's Rangers in The First Way of War, pp. 68-69.
} 
towns. Many converted to Christianity, began speaking English, and outwardly adopted aspects of European culture. ${ }^{5}$ As their appetite for the consumer goods of the transatlantic market economy increased, so did the Indians' indebtedness, which the colonists' predatory lending practices rendered chronic and persistent. To survive, Native men took jobs as common laborers and mariners, particularly as whalers. During the early eighteenth century, some were forced to indenture themselves to whites for terms ranging from a few months to as long as ten years, while women seeking to settle their debts indentured themselves, and sometimes their children, as servants in English households. Other Native women worked plots of land, dispensed herbal remedies, or produced handicrafts. Despite such attempts, settlement Indians became increasingly impoverished. For at least part of the year, some tribes and bands were dependent on the supplies provincial overseers or missionary aid societies distributed to them. ${ }^{6}$

Indian men, who faced discrimination, mounting debts, and grinding poverty, thus found it difficult to resist provincial recruiters' enticements, from cash signing bonuses to promises of

\footnotetext{
5The study of the cultural effects of colonialism on Native Americans in southern New England is extensive. Although by no means an exhaustive list, important recent works include Daniel R. Mandell, Behind the Frontier: Indians in Eighteenth-Century Eastern Massachusetts (Lincoln: University of Nebraska Press, 1996), and Tribe, Race, History: Native Americans in Southern New England, 1780-1880 (Baltimore: Johns Hopkins University Press, 2008); Jean M. O’Brien, Dispossession by Degrees: Indian Land and Identity in Natick, Massachusetts, 1650-179o (New York: Cambridge University Press, 1997); David J. Silverman, Faith and Boundaries: Colonists, Christianity, and Community among the Wampanoag Indians of Martha's Vineyard, 1600-1871 (New York: Cambridge University Press, 2005); Amy E. Den Ouden, Beyond Conquest: Native Peoples and the Struggle for History in New England (Lincoln: University of Nebraska Press, 2005); Jenny Hale Pulsipher, "Subjects unto the Same King": Indians, English, and the Contest for Authority in Colonial New England (Philadelphia: University of Pennsylvania Press, 2005); and R. Todd Romero, Making War and Minting Christians: Masculinity, Religion, and Colonialism in Early New England (Amherst: University of Massachusetts Press, 2011).

${ }^{6}$ See various overseers accounts for Mashpee $\left(1749-51 ; 175^{8-61}\right)$ and Punkapoag (1745-47), Massachusetts Archives Collection, Massachusetts State Archives, Boston, vols. 32:129; 33:179-84; 31:554a-56a. See also Silverman, Faith and Boundaries, pp. 188-99, 214-15, and Kevin McBride, "Transformation by Degree: EighteenthCentury Native American Land Use," in Eighteenth-Century Native Communities in Southern New England in the Colonial Context, ed. Jack Campisi (Mashantucket, Conn.: Mashantucket Pequot Museum and Research Center, 2005), pp. 35-56.
} 
scalp bounties. ${ }^{7}$ To encourage enlistment, provincial agents treated entire Indian communities to gifts of food, alcohol, and trade goods. Moreover, at a time when Protestant missionaries and colony officials sought to circumscribe the activities of Native American men and convert them into sedentary Christian farmers, the military offered a compelling alternative, one that honored older warrior traditions (bravery, ferocity in battle, and hunting skills) and held the promise of prestige similar to that conferred by Indian war parties. ${ }^{8}$ While the English saw military service as a means of channeling Indian aggression toward provincial and imperial ends, Native American leaders hoped that their men's contributions might carry weight in land and legal disputes and ultimately secure greater recognition of tribal sovereignty. Family and band loyalties also had an influence, for many indigenous enlistees came from interrelated communities and regularly enrolled with and served alongside kin.

New Englanders thought Indian populations living in their midst culturally inferior, but, like select other conquered peoples in the expanding British Empire, Native American soldiers serving in the provincial forces during King William's War (1689-97), Queen Anne's War (1703-13), and Governor Dummer's War (1722-26) were viewed as possessing a special aptitude for warfare, especially within a forest setting, and as absolutely vital to combating enemy Indians, who were skilled at resisting traditional English military maneuvers. Usually comprising between 15 and 20 percent of early New England military expeditions, Indian soldiers often served in autonomous, all-Indian companies commanded by English, and sometimes Native, officers. ${ }^{9}$

\footnotetext{
${ }^{7}$ Per statute, all indentured soldiers could keep enlistment bonuses, money earned from scalp bounties, as well as any plunder taken while on campaign. The Acts and Resolves, Public and Private, of the Province of Massachusetts Bay . . . , vol. 13: 1741-1747 (Boston: Wright and Potter, 1905), p. 629.

${ }^{8}$ See Romero, Making War and Minting Christians, pp. 138-40.

${ }^{9}$ Cynthia Enloe, in her Ethnic Soldiers: State Security in a Divided Society (Athens: University of Georgia Press, 1982), uses the term "ethnic soldiers" to describe certain minority groups within a multi-ethnic state deemed trustworthy by ruling elites and well suited to military service. Wayne E. Lee, in his "Subjects, Clients, Allies or Mercenaries? The British Use of Irish and Indian Military Power, 1500-1815," in Britain's Oceanic Empire: British Expansion in the Atlantic and Indian Ocean Worlds, c. 1550-
} 
Indians' role in the provincial army changed dramatically during King George's War (1744-48) and the French and Indian War. Due to Native population decline, greater imperial involvement, and the larger scale of the conflicts, Indians were less apt to serve in all-Indian units and instead were integrated into predominantly white companies. Only a handful advanced beyond the rank of corporal. Still, the demands of imperial warfare in the Northeast produced new opportunities for New England's Indian men, including positions in Gorham's ranger corps. ${ }^{10}$

The Gorham family was active in colonial New England's military affairs. John and Joseph's great-grandfather, John Gorham I, had been a commander for Plymouth Colony during King Philip's War. Their grandfather, John Gorham II, led English and Wampanoag troops during King William's War; he commanded first a company and then, later, a battalion, and he was Benjamin Church's second-in-command during campaigns against the Abenaki. John and Joseph's father, Shubael Gorham, was a veteran provincial officer of Queen Anne's War. Numerous uncles and cousins served as officers throughout the colonial era, some recruiting and commanding Indian soldiers. With the exception of the Churches, no other family was more responsible for the development of New England's Native American soldiery and the American ranger tradition than were the Gorhams and their kin. ${ }^{11}$

\footnotetext{
185o, ed. H. V. Bowen, Elizabeth Mancke, and John G. Reid (New York: Cambridge University Press, 2012), pp. 179-217, sees a "martial race" as a particular group recruited for their expertise in a style of warfare, especially one suited to local conditions but integrated into the same organizational and technological structure as the rest of an army. See also Heather Streets, Martial Races: The Military, Race and Masculinity in British Imperial Culture, 1857-1914 (Manchester, U.K.: Manchester University Press, 2004); Tom Holm, "The militarization of Native America: Historical process and cultural perception," Social Science Journal 34 (1997): 461-74; Harald E. L. Prins, The Mi'kmaq: Resistance, Accommodation, and Cultural Survival (New York: Wadsworth, 1996), pp. 85-87, 133-57.

${ }^{10}$ Other all-Indian units included three Native American companies in Roger's Rangers-two companies of Stockbridge Mohicans and one of Mohegans from Connecticut. See John R. Cuneo, Robert Rogers of the Rangers (New York: Oxford University Press, 1959), pp. 42, 82, 94-96, 127.

${ }^{11}$ Mass. Archives, 71:325, 381. Related family members included cousins Richard, Silvanus, William, and Melatiah Bourne.
} 
As they attempted to subdue Acadians and Mi'kmaq Indians who challenged English sovereignty in Nova Scotia (previously Acadia) during the 1740s, the British relied heavily on New England's Native American soldiers. ${ }^{12}$ Early in June 1744, Paul Mascerene, the governor and garrison commander at Annapolis Royal (formerly Port Royal), wrote to Massachusetts Governor William Shirley to ask for reinforcements for his besieged garrison, which was barricaded within Fort Anne. Mascerene requested " 20 or 30 bold and warlike Indians" who could "awe the Indians of this peninsula[,] who believe all the Indians [who] come from New England are Mohawks[,] of whom they stand in great fear." The Massachusetts legislature approved funding for the relief force, and in July, Shirley wrote to the Lords of Trade in England outlining his plan:

I depend upon sending to Annapolis in a few days Seventy more Soldiers raised here, which will consist chiefly of pick'd Indians and other men fit for ranging the woods under a very expert Officer for that Service, who has undertaken (and upon a probable scheme as it appears to me) to destroy and drive off all the Indians.

His man for the job was John Gorham, whose family had extensive business and maritime connections as well as political and social clout. Undoubtedly lured by a lucrative bounty, almost all of the rangers who enlisted lived near Gorham's hometown of Yarmouth, on Cape Cod. ${ }^{13}$

\footnotetext{
${ }^{12}$ Nova Scotia became part of the British Empire in 1713 , but the area was far from pacified in the 1740 os. Acadia, present-day Nova Scotia and parts of present-day New Brunswick, was ill defined, and its borders were in contention. See Geoffrey Plank, An Unsettled Conquest: The British Campaign against the Peoples of Acadia (Philadelphia: University of Pennsylvania Press, 200o), pp. 40-41, 70-72, 76, and John Mack Faragher, A Great and Noble Scheme: The Tragic Story of the Expulsion of the French Acadians from Their American Homeland (New York: W. W. Norton, 2005), pp. ${ }^{136-45}$.

${ }^{13}$ Paul Mascerene to William Shirley, 9 June 1744, quoted in George A. Rawlyk, Nova Scotia's Massachusetts: A Study in Massachusetts-Nova Scotia Relations, 16301784 (Montreal: McGill-Queen's University Press, 1973), pp. 140, 269; William Shirley, Memoirs of the Principal Transactions of the Last War between the English and French in North-America-From the commencement of it in 1744, to the conclusion of the treaty at Aix la Chapelle... (Boston, 1758), pp. 26, 28-29. New England Indians being confused with "Mohawks" probably stems from both New England Algonquians and Iroquois warriors, both in the service of the British, being stationed at Annapolis
} 
As is evident from muster rolls and other descriptions, leadership positions - including three officers, four noncommissioned officers, a company clerk, and, unique to the unit, several "boatmasters," who were responsible for the upkeep of the company's six or seven large whaleboats-were monopolized by Anglo-Americans, some of whom were Gorham's relatives. But the sixty remaining men, who made up the rank and file, were Native Americans. The vast majority, about fifty-five, were Nauset and Wampanoag Indians from Cape Cod (Barnstable County). The indigenous population of the area being in serious decline at the time, marshaling the company significantly strained the manpower resources of the area's Indian communities (see fig. 1). ${ }^{14}$

Gorham also recruited a handful of Pigwacket warriors. This tribe's traditional lands lay more than a hundred miles north of Cape Cod, along the upper Saco River in southwestern Maine and extending into the uplands of central New Hampshire. As members of the Wabanaki confederacy, an alliance of various Abenaki tribal communities in northeastern New England as well as Maliseet, Passamaquaddy, and Mi'kmaq groups, the Pigwacket were traditionally aligned with the

Royal in 1710-11. See Geoffrey Plank, "Deploying Tribes and Clans: Mohawks in Nova Scotia and Scottish Highlanders in Georgia," in Empires and Indigenes: Intercultural Alliance, Imperial Expansion, and Warfare in the Early Modern World, ed. Wayne E. Lee (New York: New York University Press, 2011), pp. 221-49. For members of Gorham's well-connected family holding positions as magistrates, missionaries, and reservation overseers, see Frederick Freeman, The History of Cape Cod: The Annals of Barnstable County and of Its Several Towns, 2 vols. (Boston, 186o, 1862), 1:378, 730-38; 2:203, 445; and The Massachusetts Civil List for the Colonial and Provincial Period, 1630-1774, ed. William H. Whitemore (Albany, N.Y.: J. Munsell, 1870), pp. $54-61,72-76,104-6,113,127,141-46$.

${ }^{14}$ The size of the unit has often been underestimated because the earliest muster roll lists just forty-one men (and only twenty-two Native Americans). But this roll in fact records a much depleted unit at the end of its first three-year deployment in 1746, not a full company at its beginning. The company initially contained seventy men, almost twice the number cited by John Grenier in The First Way of War, pp. 68-69, who also claimed that white frontiersmen were Gorham and Shirley's preferred enlistees. See undated (ca. 1746) muster roll, John Gorham Papers, Clements Library, Ann Arbor, Mich.; Joseph Gorham, "Return of Troops, Rangers from Nova Scotia," 23 February 1748, Gilder Lehrman Collection, Gilder Lehrman Institute for American History, New York; "Names officers \& men on Comd when took 3 frenchmen," 1 January $1749\left[/ 175^{\circ}\right]$, Gorham Papers (this appears to be a partial muster roll). For Indian population estimates of Barnstable County, see note 59 . 


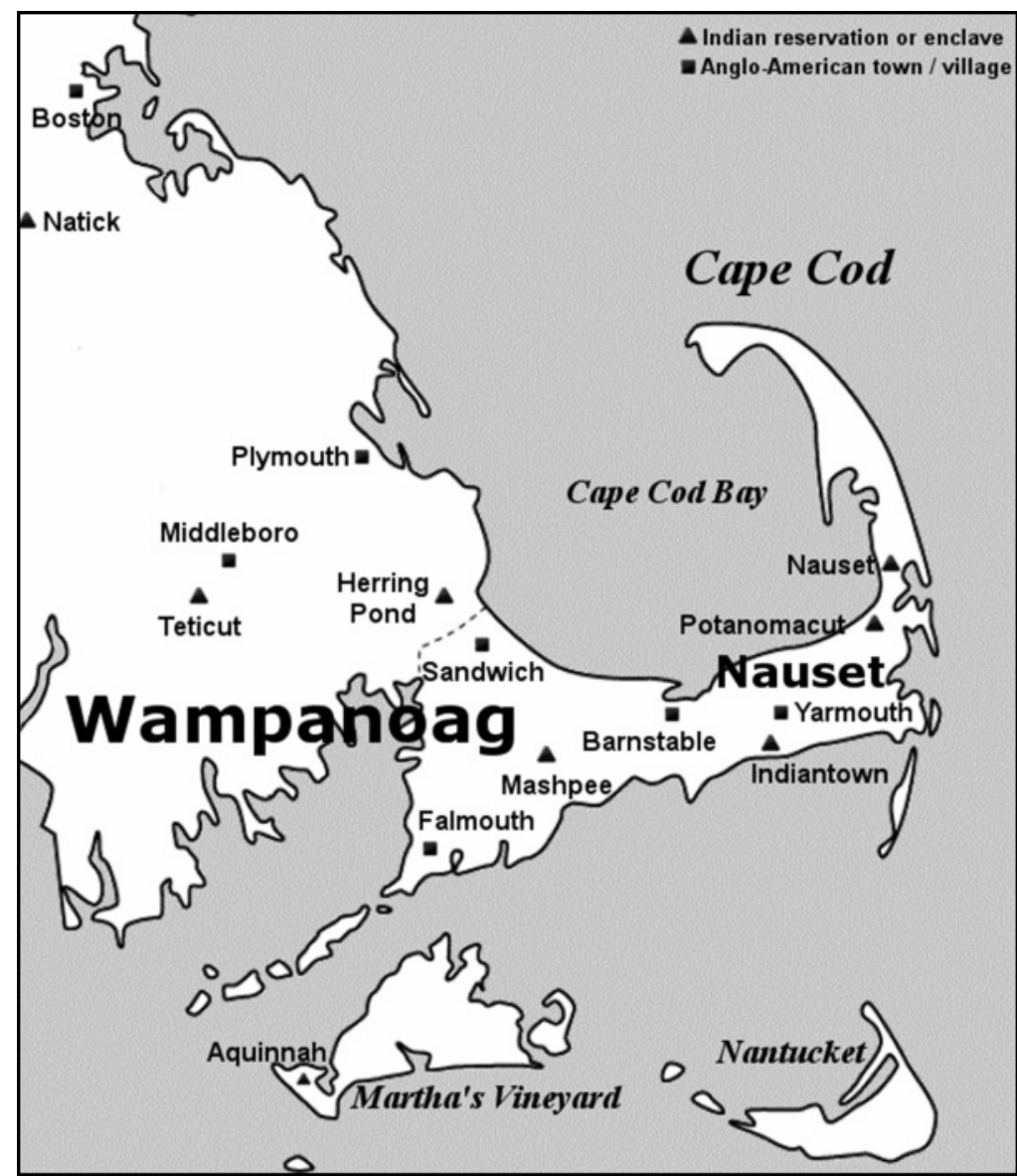

FIG. 1.-Cape Cod Indian enclaves (Barnstable County), circa 1750, the primary area of recruitment for Gorham's Rangers. Map prepared by author.

French and therefore enemies of the British. Thus, during periods of conflict, their close proximity to English settlements often forced them to flee for safety to the Saint Francis Jesuit mission at Odanak, near Quebec. In 1744, however, with King George's War looming, one small band instead placed itself under the protection of Massachusetts. Six of the men from this group agreed to serve in the provincial army and were assigned to Gorham's Rangers. As Benjamin Church had once done for bands of Wampanoag during King Philip's War, Gorham 
helped relocate and assist the Pigwacket families during wartime. ${ }^{15}$

More than skill, patronage was key to Gorham's securing his commission. His father and another relative, Silvanus Bourne, were legislators who held seats on the Governor's Council. In exchange for their support, Shirley rewarded members of the interrelated families with government posts and military commissions. Despite his impressive political connections and his family's military background, Gorham was not, like other ranger commanders (specifically Rogers), a frontiersman; nor was he a hunter nor a veteran of earlier borderland wars. Apparently he was not taught the arts of war beyond the basics every colonial Englishman learned at the local militia muster-typically a rather amateurish event. Too young to have served on any prior military campaigns, Gorham was only thirteen at the outbreak of New England's last frontier conflict, Governor Dummer's War. Following this short regional war against the Wabanaki Confederacy, colonial New England enjoyed one of its longest periods of uninterrupted peace.

Gorham's first calling was the sea. He grew up in a mercantile family far from the frontier, in Barnstable, one of the oldest towns on Cape Cod, established by the Pilgrims of Plymouth Colony in the mid-1630s. From a young age, he trained in the early whaling industry, then the most lucrative business on the Cape. According to one eyewitness, he was a "dextrous" harpooneer, and over time he became a skilled whaler, mariner, and merchant. He lived most of his adult life in coastal Yarmouth, adjacent to Barnstable, but did some land speculating and had investments, including several sawmills, in the frontier towns of southern Maine. When conflict between England and France recommenced in 1744, Gorham was

${ }^{15}$ Petition of John Gorham Esq. to the Governor and General Court of Massachusetts, Boston, 5 April 1749, Mass. Archives, 73:393-99; Correspondence of William Shirley, Governor of Massachusetts and Military Commander in America, 1731-176o, vol. 1, ed. Charles Henry Lincoln (New York: Macmillan, 1912), p. 138 . Various government dispatches deal with the Pigwacket coming into Massachusetts jurisdiction, including Mass. Archives, 31:494, 495, 501, 502; 32:2, 20-23. This band of Pigwackets settled for a time in Rochester, Mass. (see Mandell, Beyond the Frontier, pp. 130, 172). 
thirty-five years old. ${ }^{16}$ Commanding whaling vessels had prepared him to lead the rangers. It not only familiarized him with leadership, discipline, and logistics, but, most important, it gave him practical experience in recruiting and managing Indians.

During the first half of the eighteenth century, indentured Indian servants comprised the vast majority of whalers in New England's shore industry as well the first crewmen on deep-sea whaling ships departing from area ports. We know from records of two of the voyages of Gorham's sloop Neptune that his crews were primarily Indians from local Native communities-like nearby Mashpee, where his father and uncle were the provincially appointed overseers. When hunting North Atlantic right whales, Gorham's ships resupplied and refitted in Newfoundland and Nova Scotia, and so he was familiar with the Maritime Provinces, where his company would later operate. ${ }^{17}$

The company's junior officers were just as inexperienced as Gorham, but there was depth in the ranks. A number of the enlistees, the vast majority of whom were indentured Indian whalemen who worked for Gorham's family and associates, were also veteran soldiers and experienced rangers who had fought for the English in previous wars. Joseph Ralph, a village

${ }^{16}$ Journal of the Honourable House of Representatives, of His Majesty's Province of the Massachusetts-Bay in New England ... (Boston: Printed by Samuel Kneeland, 1740), p. 87; Francis G. Hutchins, Mashpee: The Story of Cape Cod's Indian Town (West Franklin, N.H.: Amarta Press, 1979), pp. 72-73, 83; Expeditions of Honour: The Journal of John Salusbury in Halifax, Nova Scotia, 1749-1753, ed. Ronald Rompkey (Dover: University of Delaware Press, 1982), pp. 115, 119.

${ }^{17}$ For Indians and early whaling, see Daniel Vickers, "The First Whalemen of Nantucket," William and Mary Quarterly, 3rd ser. 4o (1983): 56o-83, and "Nantucket Whalemen in the Deep-Sea Fishery: The Changing Anatomy of an Early American Labor Force," Journal of American History 72 (1985): 277-96; Elizabeth A. Little, "Indian Contributions to Shore Whaling," Nantucket Algonquian Studies 8 (1981): 38; Mark A. Nicholas, "Mashpee Wampanoags of Cape Cod, the Whalefishery, and Seafaring's Impact on Community Development," American Indian Quarterly 26 (2002): 162-95; Russell Lawrence Basch, "Colored' Seamen in the New England Whaling Industry: An Afro-Indian Consortium," in Confounding the Color Line: The Indian-Black Experience in North America, ed. James F. Brooks (Lincoln: University of Nebraska Press, 2002); John Braginton-Smith and Duncan Oliver, Cape Cod Shore Whaling: America's First Whalemen (Yarmouth, Mass.: Historical Society of Old Yarmouth, 2004). For Gorham's whaling interests, see "Jno. Gorham's Memorandum or Dayly Journal," 1737-38, and John Gorham's "Wast[e] Book," 1745, Special Collections [microform], Sturgis Library, Barnstable, Mass. 
leader among the Nauset, served in a similar all-Indian ranger company twenty years earlier during Governor Dummer's War. Commanded by Captain Richard Bourne (1694-1738), another of Gorham's kinsmen, the unit deployed three times to the Maine frontier in 1724-25. Its mission each time was to subdue Indian resistance to British rule, which involved raiding Abenaki villages and scouting for and skirmishing with small Native war parties. Older, more experienced in military matters, and better connected politically than Bourne, Shubael Gorham helped organize and outfit his relative's company, supplying it with much of its equipment and its special whaleboats. John knew (or would later know) many of these Indians, who went on to work on the vessels he owned. One, James Queach of Yarmouth, had also served in Bourne's company. Renowned for having killed a Norridgewock sachem in one-on-one combat, he had also scalped four or five Abenaki in a single encounter during the war. Another Nauset recruited in 1744 was Peter Dogamus, also of Yarmouth. Then in his fifties, he was probably the most experienced warrior on the Cape, having served in Queen Anne's War more than thirty years earlier in an all-Indian company recruited by Benjamin Church and commanded by Church's son. As a member of this unit, Dogamus took part in the 1710 siege and capture of Port Royal, so for him the area around Annapolis Royal was familiar territory. Like Ralph, Queach, and others in the unit, he had also served in Bourne's 1724-25 companies. Several of the Pigwacket contingent were also veterans of Governor Dummer's War, but, as members of the Wabanaki Confederacy, they had fought against the English. ${ }^{18}$

\footnotetext{
${ }^{18}$ For muster lists for Richard Bourne's 1725 companies, see Mass. Archives, 91:139-41, 178-80, 223. Bourne's unit took a leading role in the August 1724 attack on Norridgewock. See Boston News-Letter, 27 August 1724; American Weekly Mercury (Philadelphia), 1o September 1724; anon., The Rebel's Reward: Or, English Courage Display'd, Being A Full and True Account of the Victory over the Indians at Norridgewock (Boston, 1725); Grenier, The First Way of War, p. 38; Samuel Penhallow, The History of the Wars of New-England with the Eastern Indians (Boston, 1726), p. 132. The junior officers included John's brother Joseph and their cousin William Bourne (1723-70). Samuel Eliot Morison, "Harvard in the Colonial Wars, 1675-1748," Harvard Graduates Magazine 26 (1917-18): 572.
} 
The Pigwacket members, while few in number, were vital to the company's initial success. Serving from its formation through its first two deployments (until 1750), they "behav'd with Courage \& Faithfulness against our Enemies," according to Gorham. Among the Pigwackets was a man the colonists called "Captain Sam," probably the leader French sources referred to as Jérôme Atecouando, son of the sachem Atecouando, and later a celebrated orator among the Abenaki at Odanak. His Christian name, Jérôme, was sometimes rendered by the English on treaties as "Saaram," which may have been bastardized to "Sam." Probably in his mid-forties when recruited to the rangers, he had been an important leader among his people since 1729, when he first represented the Pigwacket at treaty signings. According to Gorham, the Pigwackets' intimate knowledge of Mi'kmaq territory caused their foes "no small uneasiness" during the war. A skilled guide, scout, translator, and negotiator, Captain Sam was recognized in several sources as Gorham's most trusted Indian soldier, which suggests that he was an unofficial officer, perhaps adjutant. ${ }^{19}$

\section{"Their Skulking Way of Fighting"}

Called up to "awe the local Indians," awe they did. Once on the frontier, Gorham's Rangers had a dramatic impact. "These

\footnotetext{
${ }^{19}$ Petition of John Gorham; Captain Sam, or Captain Samuel, was probably the Pigwacket/Arresaguntacook/St. Francis sachem identified in French and English records alternately as "Saaroom," "Salom," or "Jerome" (at treaty of 1727). His full name is most likely Jérôme Atecouando (rendered in colonial records variously as Atecuando, Atièouando, and Adeawando). His father, the sachem Atecouando of Pigwacket, signed the treaty of Portsmouth in 1713 (a "Capt. Sam" of Kennebec also signed). His brother was most likely a man the English called Sussup (sometimes spelled Sozap or Suzack), known to the French as Joseph Atecouando. According to Gordon Day's translation, Atecouando means "deer spirit-power" or possibly "dog spirit-power." Jerome's child might have been the renowned Molly Ockett, a famous doctor and herbalist who later married a Sussup-possibly a cousin. See Gordon M. Day, The Identity of the St. Francis Indians (Ottawa: National Museums of Canada, 1981), pp. 3, 32-38, 41-42, 67-68; Boston News-Letter, 4 October 1744; Boston Post Boy, 11 November 1744; New York Weekly Journal, 26 December 1748; Documentary History of the State of Maine, ed. James P. Baxter, vol. 11 ("Baxter Manuscripts"), Collections of the Maine Historical Society, 2nd ser. (1908), pp. 6o, 71-74; Bunny McBride and Harald E. L. Prins, "Walking the Medicine Line: Molly Ockett, a Pigwacket," in Northeastern Indian Lives, 1632-1816, ed. Robert S. Grumet (Amherst: University of Massachusetts Press, 1996), pp. 325-29.
} 
Indians, under the management of officers who understood the proper use of them, and to whose orders they were perfectly obedient," Shirley recalled, liberated Annapolis Royal. They scouted and patrolled forested areas for which "Regular Troops are by no means fit." Mascerene, too, noted that the rangers were adept at countering the forest warfare tactics of the Mi'kmaq, even as he tried to rescue English troops from a humiliating comparison with the provincial auxiliaries. Writing to the Lords of Trade in England, he reported that

the preservation of this place is owing to the reinforcement we have received from the Province of the Massachusetts Bay, and how necessary it is to set Indians against Indians; for tho' our men outdo them in bravery yet being unacquainted with their skulking way of fighting and scorning to fight undercover, expose themselves too much to the enemy's shot.

Gorham's strategy to subdue local resistance included subterfuge, "skulking," surprise attacks, and terror against enemy noncombatants, including taking captives (some used as hostages, some killed, and a few sold for servants in New England), and killing and scalping Mi'kmaq women and children. ${ }^{20}$

According to a newspaper account, "the Garrison soldiers [were] entirely unacquainted with the manner of hunting and pursuing [Indians] in the Woods, and Bush fighting in skulking parties." And so Gorham's Rangers taught them their ways. In December 1746 and January 1747 , records show that they also trained a battalion of Massachusetts provincial troops stationed at a garrison at Grand Pré, in northwestern Nova Scotia, in the basics of guerilla warfare (see fig. 2). Their brand of warfare was not uniquely Native American but represented more than a century of military innovation targeted toward and evolving out of the exigencies of the frontier. In the seventeenth century the region's Native Americans adopted firearms and

\footnotetext{
${ }^{20}$ Shirley, Memoirs of the Principal Transactions, pp. 28-29; Shirley to the Duke of Newcastle, 27 February 1746, in Documentary History of the State of Maine, 11:31415: Paul Mascarene to the Lords of Trade, 25 September 1744, in Selections from the Public Documents of the Province of Nova Scotia, ed. Thomas B. Atkins (Halifax, 1869), pp. 133-34; Grenier, First Way of War, pp. 72, 8o, 85, and The Far Reaches of Empire, p. 153.
} 


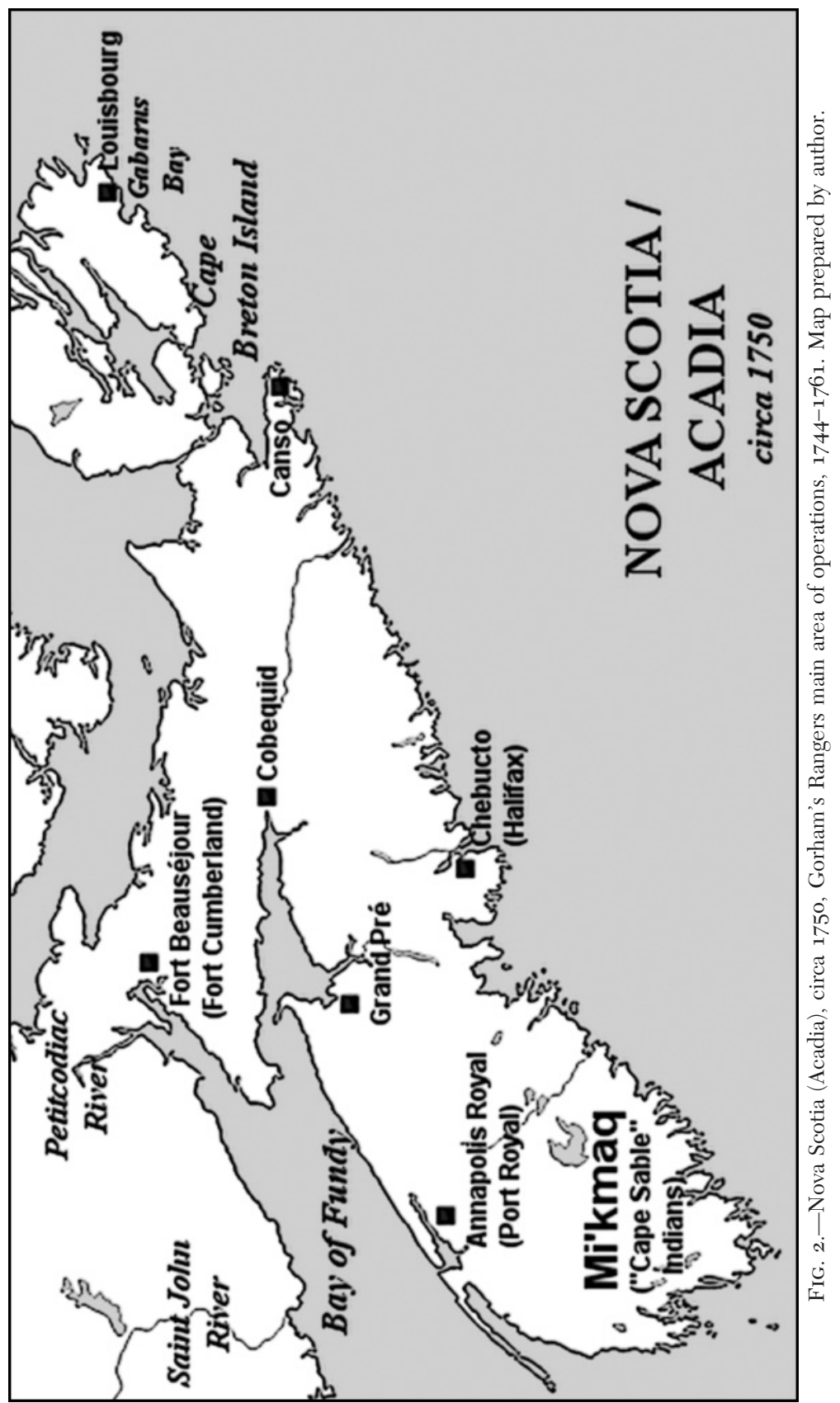


steel-edged weapons which, along with other factors, fueled competition among tribes and changed how wars were waged. The fathers and grandfathers of some of Gorham's Indian rangers had served with Benjamin Church and John Gorham II in King Philip's and King William's Wars. Many of the Wampanoag who enlisted in the rangers in 1744 had honed the techniques of the prior generation when they battled Abenaki peoples during Queen Anne's and Governor Dummer's War. Tracking enemies, maneuvering under forest cover, and skirmishing in small units were the hallmarks of colonial Native American warfare. On reconnaissance around Annapolis Royal, Indian rangers gathered intelligence on opponents and then used this information to harass them during nighttime raids on their villages. The rangers also rounded up Acadian ringleaders suspected of organizing resistance against British rule. ${ }^{21}$

In addition to their intimate understanding of the forest, many of Gorham's company were also adroit on water. Writing to Gorham in 1746, Mascerene demonstrated his appreciation for the particular contribution the rangers were making to the British war effort. "Your people being for the most part both soldiers, sailors and wood rangers," he noted, they "were [well] acquainted in the way of annoying the enemy we have to deal with." Gorham agreed. Acadia "was so cut and divided by water that nothing but Whaleboats and Men used to them could gain advantage over [the] Indians there; whose dependence lay so much in the swiftness of their canoes." ${ }^{22}$

Gorham was well acquainted with his whalemen's dexterity. Joseph Ralph had been the "endsman"- the man who steered the boat and launched the harpoon - of an Indian whaleboat crew on one of Gorham's sloops. From 1744 until his death in 1749, Ralph soldiered for his old skipper in Gorham's Rangers. Before the war, corporal Jeremy Queach, one of the few Natives awarded noncommissioned officer rank in the rangers, worked as a whaler for Benjamin Bangs of Harwich. Another

\footnotetext{
${ }^{21}$ Boston News-Letter, 15 November 1744; Mascarene to the Lords of Trade, 25 September 1744; Grenier, First Way of War, pp. 74-75; Shirley, Memoirs of the Principal Transactions, pp. 28-29.

${ }^{22}$ Correspondence of William Shirley, 1:339; Petition of John Gorham; Church, The History of Philip's War, p. 213.
} 
Nauset, Joseph Twiney, also from Harwich, was in the rangers from 1748 through $175^{2}$, when the company was stationed at Annapolis Royal and, thereafter, Halifax. During that time, he amassed a considerable debt to Edward Winnet, the captain of one of the ranger's transports, from whom he had borrowed money because, like others in the company, Twiney was an indentured servant and so his wages were sent to his English master back on Cape Cod. At the end of his enlistment, Twiney had the choice of indenturing himself to Winnet as a whaler or going to debtors' prison. He chose whaling. If the connection between whaling and the ranger service was not clear enough, on 14 October 1744, Gorham and ten Indian rangers daringly rowed their whaleboat up to an armed French warship entering the harbor at Annapolis Royal. A whale surfaced nearby. The whaling captain and Indian whalemen followed their instincts; they attacked the whale instead of the ship. ${ }^{23}$

The force quickly earned a reputation as effective guerilla fighters who instilled fear in their enemies, just as Mascerene had hoped. Shortly after arriving at Annapolis Royal in 1744, a Massachusetts newspaper reported that "Capt. Gorham who commands a Company that went thither from this province, had lately brought into that Garrison the scalps of three of the Cape Sable's or St. John's Indians [Mi'kmaqs]; also a Papoose alive." In the autumn of 1749 , the rangers sparked an international incident when, unprovoked and in spite of a truce, Gorham's unit crossed into French-controlled territory, captured two Abenaki peace envoys, and demanded at gunpoint that the Mi'kmaq of

\footnotetext{
${ }^{23}$ Joseph Ralph married Deborah Joel at the Indian meetinghouse in Yarmouth on 24 September 1727 (Vital Records of Yarmouth, Massachusetts, to the Year 1850, comp. Robert M. Sherman and Ruth Wilder Sherman [Providence: Society of Mayflower Descendants in Rhode Island, 1975]). For Ralph's service on the Neptune, see John Gorham's "Waste Book"; for reference to Ralph as an "Indian Justice," see "Vital Records of the Towns of Eastham and Orleans," Mayflower Descendant, various issues, 1901-35. For Queach, see Benjamin Bangs Diary, vol. 1: 1741-49, Massachusetts Historical Society (MHS), Boston, entries for 19-20 September 1744; see also undated (ca. 1746) muster roll of Gorham's Rangers. For Twiney, see Nathaniel Stone, account against Captain Joseph Winnet, 1751, Bourne Family, Massachusetts Military Papers, Houghton Library, Harvard University, Cambridge, Mass. In early August 1751, John Salusbury recalled how John Gorham set out in a boat and "killed a Porpoise in a Whaleing manner" (Expeditions of Honour, pp. 115, 119). Seemingly apocryphal, the incident with the French ship and the whale was mentioned alongside observations that can be corroborated in other sources (see Boston News-Letter, 15 November 1744).
} 
the Saint John River region submit to British authority. That same year, a party of Mi'kmaq ambushed a construction crew on the outskirts of Halifax. Rather than the local militia, officials sent Gorham and his rangers in pursuit because they could "fight them in their own way," meaning they utilized ranger tactics. ${ }^{24}$

The way in which the rangers fought attracted a good deal of attention. Like Church decades before and Rogers a decade later, Gorham eschewed massed-infantry tactics, whereby soldiers in tight formation fired largely un-aimed volleys at the opponent's line, the norm in conventional European warfare. Instead, he emphasized marksmanship, that is, shooting at individual targets. The rangers' waterborne operations were also admired. A detachment from the Seventh Massachusetts Regiment, including Indians from the rangers, was the first unit ashore at Gabarus Bay on 4 May 1745, at the start of the expedition to seize Louisbourg from the French. Led by Gorham and using whaleboats and ranger tactics, the detachment engaged two hundred French soldiers sent to repel them. But it was the French force that was surprised and quickly surrounded by Gorham's smaller force. A New Englander observing the mêlée recounted it.

We had but 100 landed, under Col. Gorham, who did not stay to draw up in form, but surrounded the French, and kept popping at them, kill'd 4 or 5 and wounded several, and took a great many prisoners.... In landing we had 2 men wounded. The French say our Men fight like Devils; for go which way they will they are popping at them like true Indian hunters.

They fought like Indians because many of them were Indians. Surviving records indicate that two out of every five privates

\footnotetext{
${ }^{24}$ New York Weekly Journal, 19 November 1744; Documents Relative to the Colonial History of the State of New York, vol. 6, ed. John R. Brodhead and E. B. Callaghan (Albany, 1855), pp. 478-84; New York Mercury, 5 June 1756; John Knox, An Historical Journal of the Campaigns in North America for the Years 1757, 1758, 1759, and 1760, 3 vols. (Toronto: Champlain Society,1914-16), 1:394-95; Roland-Michel Barrin de La Galissoniere to Shirley, 26 June and 25 July 1749, in Report Concerning Canadian Archives for the Year 1905, 3 vols. (Ottawa: S. E. Dawson, 1906), 2:54, app. N-303306; Boston News-Letter, 12 October 1749.
} 
in the Seventh Massachusetts were Native Americans. Like the rangers, they were mostly Wampanoags from Cape Cod, as well as from Plymouth and Bristol counties, Martha's Vineyard, and Nantucket. ${ }^{25}$

In addition to amphibious landings and skirmishing tactics, Gorham and his Indian rangers frequently employed stealth and subterfuge. Fluent in French, John Gorham convincingly impersonated a Canadian officer on several occasions to gather intelligence or take prisoners. Joseph Gorham, at the time a lieutenant, and sixty rangers raided the Acadian settlement at Cobequid in late 1749. The Abbé Jean-Louis Le Loutre (170972), a leader of the Acadian resistance in the area, noted that "Mr. Gorom came stealthily and at night, and carried off our pastor and our four deputies. . . . he is ordered to seize upon all the guns found in our houses, and consequently to reduce us to a condition similar to that of the Irish." Le Loutre understood British intentions; the Acadians fought a bitter partisan struggle against the English from the late 1740 os through the 175 os. $^{26}$

\section{Captured, Assimilated, Reedemed-but Not Rewarded}

Like English soldiers (as well as many civilians), Indians from southern New England who were fighting in the colonial wars were occasionally captured by French-allied Indians. A more

${ }^{25}$ John Gorham, Journal [Fort Sackville, Nova Scotia], 9-16 September 1749, John Gorham Papers. Gorham's rank in the British army was captain. His provincial rank was lieutenant colonel. Some sources confuse him with his father, a colonel. On the landing, see Boston Evening Post, 20 May 1745. On the composition of the Seventh Regiment, see Charles Hudson, "Louisbourg Soldiers," New England Historical and Genealogical Register 25 (1871): 6o-62, and "Lt. Colonel John Gorham's Regiment," 20 November 1745, William Pepperell Papers (1664-1782), microfilm reel 2, MHS. From the rolls, 34.6 percent of the regiment's men can be identified as either Indians, mulattoes, or mustees. If one excludes officers and noncommissioned officers, Indians made up 41.4 percent of all privates.

${ }^{26}$ Papers Relating to the Forcible Removal of the Acadian French, 1755-1768, ed. T. B. Akins, Selections from the Public Documents of the Province of Nova Scotia, vol. 2 (Halifax: Charles Annand, 1869), pp. 231-32. For information on Le Loutre, see Gérard Finn, "Le Loutre, Jean-Louis," Dictionary of Canadian Biography Online (University of Toronto / Université Laval), http://www.biographi.ca. For more on the insurgency led by Le Loutre, see Grenier, The Far Reaches of Empire, pp. 138-76, and John Gorham to William Shirley, 4 October 1746, John Gorham Papers. 
complex cultural phenomenon than can be fully treated here, mourning war practices were common to cultures throughout the colonial Northeast and often determined the fate of war captives, who were apprehended to avenge or stand in for deceased loved ones. Captives could be ritually tortured and killed to assuage their captors' grief; adopted into captors' families and community to replace lost members; or ransomed to French colonists in Canada, by this time an important source of money and trade goods for many Native communities. ${ }^{27}$ The numerous narratives written by former captives are a valuable source for historians, anthropologists, and literary scholars, for they provide rich descriptions of intercultural encounters as well as important, albeit problematic, ethnographic accounts of indigenous culture. They are limited, however, for all were prepared by Euro-Americans, none by Indians. Still, Indians who were captured and later redeemed did submit petitions for back pay and pension requests to provincial authorities, and these documents raise crucial questions about citizenship, race and identity, the role of Indian family members in securing the release of captured loved ones, and the responsibility of provincial governments to their Native subjects.

On 6 July 1749, the Boston News-Letter printed a letter detailing English efforts to redeem men and women captured and imprisoned in Canada during King George's War. Tacked to the end was a notice: "We also hear, that there are nine Cape Cod Indians at Canada, five of which were taken at Annapolis Royal, who were under the Command of Col. Gorham in the year 1745; some of them are sold as Slaves to the Indians; that they are very desirous of being redeemed." 28 In May 1745, approximately five hundred French soldiers, Acadian

${ }^{27}$ Jon Parmenter, "After the Mourning Wars: The Iroquois as Allies in Colonial North American Campaigns, 1676-176o," William and Mary Quarterly 64 (2007): 3982; Peter J. Way, "The Cutting Edge of Culture: British Soldiers Encounter Native Americans in the French and Indian War," in Empire and Others: British Encounters with Indigenous Peoples, 160o-185o, ed. Martin Daunton and Rick Halpern (Philadelphia: University of Pennsylvania Press, 1999), pp. 131-35; Stephen Brumwell, Redcoats: The British Soldier and War in the Americas, $1755^{-17} 6_{3}$ (New York: Cambridge University Press, 2006).

${ }^{28}$ Boston News-Letter, 6 July 1749 . 
militiamen, and their Native American allies had attacked the garrison at Annapolis Royal and seized the Indian rangers as well as English crewmen from two provincial supply schooners, Seaflower and Montague. Over the next two months, in a journey of more than five hundred miles, the prisoners were marched across Nova Scotia to present-day New Brunswick, up the Saint John River and overland to Quebec, where they arrived on 25 July. All of the English captives and one Native American soldier were imprisoned in the city; the remaining captive Indians were re-adorned in the clothing and hairstyles of their Abenaki and Huron captors and dispersed into Indian communities around Quebec. Phineas Stevens encountered several of the captured rangers while on a diplomatic mission to Canada. He concluded that they despaired of ever being redeemed. Stevens wrote, they "take it very hard that they are not treated as the rest of King George's subjects," suggesting that they felt the English had an obligation to secure their release yet had abandoned them because they were Indians. ${ }^{29}$

The fate of the five captured rangers can be traced in surviving records. Two living in Native American villages began as "slaves" but in time, like many Anglo-American captives, were fully assimilated into the Indian communities in which they resided, where they chose to stay rather than return to New England after the war. Isaac Peck, a Wampanoag, remained among the Abenaki at the Saint Francis mission at Odanak, where he converted to Catholicism and took a wife. There he would have encountered men he knew from his days in Gorham's company. Three of his Pigwacket comrades-Captain Sam, Sabbatis, and Keysor-relocated their families to the mission rather than returning to New England. Another captive ranger, Philip Will, was a tall, lanky fourteen-year-old when he was captured in 1745 . Like many other rangers, he was an indentured Wampanoag servant, probably a Mashpee, who had been raised in an English household. At his master's home in Barnstable, he learned to read and write English before going to Nova Scotia with the rangers. Adopted by the Arosaguntacook

${ }^{29}$ Mass. Archives, 38a:148. 
(Androscoggin), a band of Eastern Abenaki who lived on the southern Maine coast, over time the child-soldier grew into manhood, took a new name, and eventually became the band's sachem. In this capacity, he put his literacy to good use in negotiating with colonial officials over land disputes between his adoptive tribe and English settlers who had invaded the region after the war. ${ }^{30}$

Other rangers, however, clearly wished to return home. Jacob Chammock, from the Herring Pond reservation in Plymouth, Massachusetts, was held by the French in Canada. Unsuccessfully attempting to escape several times, he was finally released after two years. Peter Dogamus, despite being one of the rangers' most experienced warriors, was likewise apprehended. Savagely beaten by his captors during the trek from Nova Scotia to Canada, he resided in an Indian village near Quebec, probably the small Huron community at Lorette, for the next five years. According to his later pension request, his status there remained akin to that of a servant or slave, which, as other evidence suggests, was not uncommon. Most captive Native American soldiers seem to have been treated more harshly than their white counterparts. ${ }^{31}$

The families of these and other captured Indian rangers barraged Gorham with petitions, urging him to redeem their

${ }^{3}$ For Peck, see Joseph Gorham, "Return of Troops, Rangers from Nova Scotia," 23 February 1748, Gilder Lehrman Collection; Emma Lewis Coleman, New England Captives Carried to Canada, 2 vols. (Boston, 1897; repr. 2008), 2:402. For Will, see George A. Wheeler and Henry W. Wheeler, History of Brunswick, Topsham, and Harpswell (Boston, 1878), p. 3 .

${ }^{31}$ The account of Dogamus's capture is taken from his pension request, Mass. Archives, 73:744, and The Journal of Captain William Pote, Jr., during his Captivity in the French and Indian War from May 1745 to August 1747 (New York, 1896), pp. 59-6o, 62-63, 86. Although Pote does not mention Dogamus by name, he does refer to Jacob Chammock and Caleb Popmonet and describes several other Indian soldiers traveling with him. See also Mass. Archives, 91:139-41, 178-8o; Collection de Manuscrits Contenant Mémoires, et Autre Documents Historiques Relatifs à La Nouvelle-France, Recueillis aux Archives de la Province de Québec, ou Copiés à L'Étranger, vol. 3 (Quebec, 1884), pp. 488-89, 491; records in the Mass. Archives that describe redeemed captive Indian soldiers reporting being treated as slaves or servants include: Joseph Joseph (79:564); Nathan Joseph (84:302-20); John Pequet (33:194-94a); Aaron Conkaney (84:317); Philip Metack (33:73); and Joseph Metack $(33: 133,161-62,224)$. The author would like to thank Andrew Pierce for the last two citations. 
missing family members or to aid them directly or secure the province's financial assistance to alleviate the hardships they suffered in the wake of their family member's captivity or death. Some even threatened legal action against Gorham. Writing to Shirley in 1749 to request relief for "the Squas and heirs," Gorham complained that compensation for Mi'kmaq scalps and prisoners taken during the 1744 siege of Annapolis Royal was still outstanding. Prisoners and scalps had been sent back to Massachusetts in expectation of the bounty the colony had offered, but, the commander explained, "some clause" in the statute's wording had "delayed the payment." When they learned that they might not receive their bounties due to a technicality, one that smacked of the deceitfulness that had characterized land deals with the English over the years, the rangers were livid. In a petition to the General Court, Gorham stated that in early 1745 his company's Indian members "Desired and Impowered" him to return to Massachusetts and demand the bounties from the legislature. ${ }^{32}$

Southern New England Natives living under colonial jurisdiction had, by the 1740 s, a long tradition of petitioning provincial overseers, governors, and legislatures for redress. Far from passive victims of colonial exploitation, the Indians persuaded their overseers to mediate disputes with town and colony officials, and they were not above petitioning the Crown if local governments proved unresponsive. Within a military context, however, few provincial troops, despite famously viewing their martial obligations contractually, would have thought themselves in possession of any form of power which they might choose to assert or transfer. But Gorham's language conveys that understanding of a constitutive body (the Indian soldiers) issuing an order to its representative (their commander). The rangers' "empowerment" of Gorham also reflected the consensus model that characterized southern New England Native politics. The group having come to a decision, their commander, here assuming the role of a sachem, was compelled to act on it. If he did not, as earlier colonial conflicts had amply 
demonstrated, Indian soldiers would display their displeasure by deserting or refusing to reenlist. ${ }^{33}$

The scalp bounties were not only a potent recognition of Indians' war prowess; they were for many rangers and their families the only money they would receive for their service. Provincial muster rolls show that about one-third of New England Indians in the armed forces were indentured servants. Their masters received their pay. Perhaps another third were deeply in debt and signed over or promised their wages to creditors, in some cases even before they had deployed. Thus, the majority of the region's Native American soldiers received little or nothing in hand for having risked their lives. By law, masters and creditors could attach base pay but could not touch what was earned beyond wages, including enlistment bonuses, plunder, premiums for captives, and scalp bounties. ${ }^{34}$

Before the General Court had a chance to hear Gorham's petition on behalf of his Indian soldiers, the region was again swept up in military preparations. The distracted assembly, consumed with the forthcoming siege of Louisbourg in the summer of 1745 , never returned to the petition, which was subsequently destroyed in a fire along with Gorham's accompanying documentation, and for the next seven years the bureaucratic process continued to unravel. Many Indian families entitled to a share of the scalp bounties were convinced that Gorham had been duplicitous in the affair. Desperate to escape the constant pestering of the "squaws," Gorham submitted additional petitions. But the company was in limbo, caught in a transition (1747-48) between a provincial auxiliary unit and a regular

33Mandell, Behind the Frontier, p. 157; Alden T. Vaughan, Transatlantic Encounters: American Indians in Britain, 1500-1776 (New York: Cambridge University Press, 2006), pp. 176-79, 313; and Mark D. Walters, "Mohegan Indians v. Connecticut (17051773) and the Legal Status of Aboriginal Customary Laws and Government in British North America," Osgoode Hall Law Review 33 (1995): 785-829. Mohegans throughout the colonial period often challenged the authority of their Anglo-American commanders. They refused to fight for the English for more than two years during Queen Anne's War over the same issue facing Gorham's company in 1745-nonpayment of scalp bounties.

34"Rolls of Enlisted Men .. . [1745-1749]," and "Transfers of Wages [1748-1749]," French and Indian War Papers, Connecticut Historical Society, Hartford, Conn. See also n. 7 . 


\section{To the Publifher of the Gazetre.}

Pleafo to infort tbis in your next, wbicb may fave muab Thre, Exspinct and Paper, to any tbat may bo interefeed in tbo follocuing Notification. 7 Hit is to defice all Perfone acquainted with the Indian Soldiero now living thas were as Annapolis under my Command when the Scalps and Indian Prifoner was obrained in the $X_{\text {ear }} \mathbf{7 4 4}$, om their squaiw, or any others impowred by them, that I have not as yet received one Earthing for the Scalpt, and have been obliged to maintain the Indian Prifoner then taken at my own Coft ever fince; bue am not quite oue of Hopes of being confidered its the price of Scalps, when Iobtain the Bounty ; at which Time I fhall immediately inform all Claimers when $I$ receive it, and muft defire they would defift coming or fending any Orders on that Account foc the prefento

Ry tbeir Gaptain and Follow-sufferer.

\section{J. Gorham.'}

FIG. 3.- John Gorham placed this notice about scalp bounties in the Boston Gazette, 14 April 1747, to notify rangers and the families of deceased or imprisoned company members that he was having difficulty obtaining payment for Mi'kmaq scalps they had taken in 1744. Image courtesy American Antiquarian Society.

army force. During this period, Gorham footed the company's expenses, expecting that he would be reimbursed, and so he lacked the wherewithal to compensate the families of rangers who had been killed or captured (see fig. 3).

By $175^{1}$, when the assembly finally took up Gorham's new petitions, his company had already been absorbed into the British army. The parsimonious Massachusetts legislature took the easy out, claiming that the scalp bounties were no longer within its jurisdiction. Moreover, King George's War was over, and, aside from a few frontier garrisons, the Bay Colony had recalled and disbanded its provincial forces. Its mission now aligned more with imperial goals than with those of Massachusetts, Gorham's unit stayed on in Nova Scotia. Meanwhile, having been absent from Massachusetts for the better part of six years, Gorham was losing clout. His father had died in 1746, and so John no longer had Shirley's ear. Disheartened by his repeated failures with the provincial government, Gorham petitioned his newly ordained military superiors in England to clear his accounts relating to the company. Before a settlement was reached, Gorham died (in 
late 1751).35 The bounties went unpaid. The Indian families from the Cape never received the money owed them.

Unpaid bounties aside, in January 1749, the deluge of petitions and requests from the rangers' family members, none of which survive, spurred both Crown and province to take a greater interest in the plight of those who had been captured and were languishing in Canada. Lieutenant Governor Spencer Phips organized a committee to investigate the matter. Led by Thomas Berry, a judge and legislator from Ipswich and member of the Governor's Council, the committee recommended that Phips write to the governor of Canada to inform him that "the Indians Captivated from Nova Scotia in the late War, are Subjects of the King of Great Britain having been born within this province." Therefore, Berry continued, they should "equally enjoy the privileges" thereof, and the French should "forthwith give Liberty, and Signifie it to any and every Indian (that may still remain in Canada Captivated as aforesaid) his leave for them to return to this Province and by no means to detain them against their wills" nor continue to allow them to be "sold for Slaves." $3^{6}$ Agreeing to an exchange, French officials began the task of locating Indian captives within their borders.

Despite their efforts, only one Indian ranger, Peter Dogamus, declared himself ready to return. Along with a number of Anglo-American captives desiring repatriation, he was brought to Fort Saint-Frederick (later Crown Point) in July 1750. A few weeks later, the individuals were exchanged for French prisoners held by the English. Dogamus then made his way back to New England, and in January 1751 he was in Barnstable seeking assistance from Melatiah Bourne, Gorham's cousin and business agent in New England. Bourne helped Dogamus, now more than sixty years old, obtain a pension from the province

\footnotetext{
${ }^{35}$ For more on the bounty issue, see John Gorham to Mascerene, November 1749, John Gorham Papers; Boston Post-Boy, 9 March 1752; and John Gorham Petition.

${ }^{36} \mathrm{~A}$ royal proclamation arrived from Whitehall a month later echoing the substance of Berry's report (Mass. Archives, 31:686, 692). Gorham notes in his 1749 petition to the Massachusetts General Court that he had been receiving these requests and petitions from Indian families for several years and further mentions that the accompanying documentation submitted with his later petitions was destroyed in a courthouse fire.
} 
based on his forty-plus years of service and the suffering he had endured as a captive in Canada. In his pension request to Phips, Dogamus, with Bourne's help, described himself as having "grown old \& spent great parts of his life in ye Service." Claiming he was "not able to support himself," he asked Phips to grant him an allowance. Hardly treated like a subject of the king or an inhabitant of the province entitled to certain rights, as Berry had recommended two years earlier, Dogamus encountered an assembly only slightly less tight fisted than the one Gorham had petitioned. Granted no back pay for his time in captivity, Dogamus was awarded only $£ 6$ per annum, onequarter to one-third of what a provincial soldier earned in a nine-month deployment. ${ }^{37}$

\section{"Scouring the Country of the Deluded French"}

During the Seven Years War, Gorham's Rangers was the brutal fist of British imperialism in the Maritimes. Generally portrayed as early "special forces" or frontier super-soldiers, colonial rangers in that conflict, especially Roger's Rangers, are often highly romanticized. The truth is far from glamorous. The role the British army assigned to Gorham's Rangers was to terrorize, persecute, and deport civilian populations-Acadians and Mi'Kmaq in Nova Scotia and current-day New Brunswick and, later, Canadians around Quebec. Functioning more often than not as an occupation force battling a loosely organized guerilla insurgency, the rangers were both feared and renowned for their cruel treatment of civilians and captives as well as for the devastation they wrought in a series of punitive, scorched-earth campaigns. By the era's European military standards, the unit did little real fighting, although it did participate in a number of crucial operations during the war-the taking of Fort Beauséjour in 1755, the assault on Louisbourg in $175^{8}$, the siege of Quebec in 1759 (in which they figured prominently), and in 1762 the expedition to Havana, where

\footnotetext{
${ }^{37}$ Mass. Archives, 73:744. Evidence suggests Indians received less than white veterans, perhaps because Natives could draw on tribal funds managed by reservation overseers.
} 
most of the company died. On these occasions, they served alongside other ranger companies, as many as five or six working together in a corps, as well as with British army regulars. But unlike Gorham's Rangers, these other units had no Native Americans. ${ }^{38}$

Ambush, stealth, surprise raids, scalping, and terrorizing civilians continued to characterize the company's tactics. In February 1756 , the rangers under Joseph Gorham attempted their most elaborate deception. Wearing captured uniforms and impersonating French soldiers and their Indian allies, Gorham and his men sailed a captured French sloop up the Saint John River in present-day New Brunswick to infiltrate enemycontrolled territory, gather information, and take prisoners. Four months later, on 10 June 1756 , on assignment to root out Acadian resistance in southwestern Nova Scotia, Gorham dispatched a detachment of Native American soldiers to reconnoiter an area along the banks of the Pubnico River. A small party of Acadian guerillas fired on them. The rangers caught one of the men-whom they killed and scalped - before burning all the nearby houses and crops in retaliation. And on 1 July 1759, during the siege of Quebec, Joseph Gorham and the rangers ambushed a party of enemy Indians who attempted to surprise the British encampment at Île d'Orléans, capturing and scalping nine of them. ${ }^{39}$

Gorham's Rangers was also instrumental in Le Grand Dérangement, or the Acadian Removal. Imperial officials ordered the French-speaking Catholic Acadians expelled from Nova Scotia in 1755 because of their perceived disloyalty and in order to make room for Protestant English colonists. Aiding regular troops, who had been recruited largely in New England, rangers rounded up thousands of Acadians from Nova Scotia and present-day New Brunswick between 1755 and 176o who were then deported to other British colonies and later

\footnotetext{
$3^{8}$ Gorham attempted to re-form the unit in 1763 (see Joseph Gorham [to Melatiah Bourne?], 3 September 1763, and Recruitment Account of Lieutenant William Barron [1763], Bourne Family Papers, 1687-1791, Houghton Library).

39 Papers Relating to the Forcible Removal, pp. 296-98; New York Mercury, 5 July 1756; Knox, An Historical Journal, 1:394-95 and 3:343-44.
} 
Louisiana (where they became known as Cajuns). Some, hoping to stay, took loyalty oaths, which proved ineffective. Others evaded British troops for weeks, months, or years, while still others fought back in a desperate insurgency. Especially in such cases, rangers were employed "in scouring the country of the deluded French who had unfortunately fallen under the bann of British policy," remembered one witness. ${ }^{4^{\circ}}$

Even before the British ordered the Acadians deported, they lived in fear of the rangers. Uncooperative Acadian families, labeled "malcontents" by Shirley, often had their houses and fields burnt by Gorham's company. As early as the winter of 1746, years before the actual removals, rumors spread among Acadian communities that the rangers would be evicting them from their homes. In September 1749, Gorham wrote that when the rangers, then at the head of Chebucto Bay (later Halifax), ran short on supplies, they pillaged French farmsteads in search of peas, beef, and mutton, requisitioned sawn lumber to build rafts, and seized canoes for transportation. As on many previous occasions, they also "caught a french [sic] man" and "obliged him" to act as a guide. "All ye Inhabitants seem to be mutch frightne'd in being robbed by the Indians" in the company, Gorham reported, and "could not be prevailed upon to Give us any assistance but by [use] of Force." When the rangers passed through one hamlet, Gorham noted, not surprisingly, that old men, women, and children cowered in their presence. $^{41}$

More so than during King George's War, during the Acadian Removal and the French and Indian War, Gorham's Rangers operated as a specialized amphibious strike force. Attacking suddenly and without warning from the sea, they assailed communities along the coast and, traveling upriver, struck at inland

$4^{\circ}$ Plank, An Unsettled Conquest, pp. 140-58; Faragher, A Great and Noble Scheme, pp. 397-415; Papers Relating to the Forcible Removal, p. 141.

${ }^{41}$ Gorham, Journal [Fort Sackville, Nova Scotia]; John Gorham to Shirley, 15 November 1746, Documentary History of the State of Maine, 11:344; Grenier, The Far Reaches of Empire, p. 132. One observer noted that to the Acadian inhabitants, Gorham's Rangers were "far more terrible than European soldiers" (W. Bollan to Duke of Newcastle, 19 August 1747, and Shirley to Duke of Newcastle, 27 February 1746, Documentary History of the State of Maine, 11:314-15, 387-88). 
hamlets as well. Using their ubiquitous whaleboats, they descended on an Acadian hamlet near Canso on the evening of 31 July 1757, surrounded it in the pre-dawn hours, and at first light utterly destroyed it. In September and October 1758, the rangers led a two-hundred-fifty man expedition to Cape Sable in southwestern Nova Scotia, near present-day Yarmouth. Ascending the Tusket, Pubnico, and Chebogue Rivers in their whaleboats, they expelled the remaining Acadians from the region. Then, in late October through November, Gorham's unit joined a force of over fifteen hundred soldiers that once again ascended the Saint John River in search of Acadian refugees. Also charged with erasing the Acadian presence from the landscape, they torched farms, houses, even whole villages, killed livestock, and confiscated or destroyed crops. Given the rangers' expertise at water-borne operations, in May 1759, Major General James Wolfe ordered them to row up the Saint Lawrence River on an advance reconnaissance mission, during which they secured landing sites and several strategic points before the larger invasion force arrived in June to lay siege to Quebec. ${ }^{42}$ In the aftermath of one amphibious landing that year, a British officer commented that

at day-break, [Gorham's detachment] got into their boats, and rowed to [St.] Paul's bay; when they came within reach of the shore, they were saluted with a shower of musketry, by which one man was killed, and eight were wounded; . . . before the villagers could load again, the boats were grounded, and the troops instantly pushed on shore, charged, and routed the wretched inhabitants. ${ }^{43}$

${ }^{42}$ Joseph Gorham, "A report of the proceedings in the Schooner Monckton, Beginning July 22, 1757," Huntington Library, San Marino, Calif. (citation courtesy of Geoffrey Plank); Joseph Gorham to Captain Cathcart, 23 December 1757, Rare Books and Manuscripts Collection, Boston Public Library; "Nova Scotia-Major Morris Report1758," Collections of the Massachusetts Historical Society, vol. 9 ("Aspinwall Papers"),

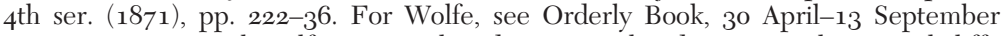
1759, Major General Wolfe's General Orders, Townshend Papers, vol. 7, Northcliffe Collection, Archives Canada; Knox, Historical Journal, 2:22; Joseph Gorham, "Account from Isle aux Coudre, dated August 16th 1759, of the Proceedings of the Company of Rangers Commanded by Capt. Gorham," Boston News-Letter, 6 September 1759; James Wolfe to Robert Monckton, 17 May 1759, Monckton Papers, vol. 22, Northcliffe Collection.

${ }^{43}$ Knox, Historical Journal, 2:38. 
Gorham's Rangers, along with companies from Rogers's corps, participated in the second siege of Louisbourg in June and July $175^{8}$. Over five hundred strong, the six ranger companies were still a mere 5 percent of the total force, but they faced a challenging initial assault — a difficult and dangerous amphibious landing, on a rocky, craggy outcropping in Gabarus Bay, in heavy fog and high surf. Raked with French gunfire and sprayed with canisters of grapeshot, a combined force of rangers, British light infantry, and highlanders rowed to their destination and waded ashore. Scaling a rock-strewn escarpment, they flanked several enemy defensive positions; then they poured into the French entrenchments, killing more than a hundred defenders and taking dozens prisoner. After this initial assault, the rangers receded to the edges of action, where they periodically skirmished with Indians, an occupation that made better use of their talents than digging trenches, constructing siege batteries, or hauling artillery, tasks required of those besieging European gunpowder fortresses. Still, their effectiveness was not to be denied. Calling them "savages," French soldiers fled at the mere sight of Gorham's company. Their fear was warranted. White and Indian members of the ranger companies killed and scalped both European and Native prisoners during the siege. Although British officers were shocked, the governor of Nova Scotia praised the rangers' performance. "I have particular pleasure in assuring you," he informed the press, "that the Companies of Rangers raised in New-England behaved at [the] Landing so as to do great Honour to themselves, and the country they come from." He made no reference to them killing prisoners and mutilating corpses. ${ }^{44}$

44The total force was eleven thousand strong (Knox, Historical Journal, 1:32, 39394). Forty-two members of this combined landing force were killed in the assault, and twenty were wounded. See The Journal of Jeffery Amherst, ed. J. Clarence Webster (Toronto: Ryerson Press, 1931), pp. 49-51; James Abercromby to Robert Monckton, 23 June $175^{8}$, and entries for 8 June, in "Journal of the Siege of Louisbourg 1758," Monckton Papers, vol. 9. For newspaper accounts of the assault, see French and Indian War Notices Abstracted from Colonial Newspapers, vol. 3: 1 January 1758-17 September 1759, ed. Armand Fransis Lucier (Lanham, Md.: Heritage Books, 2007), pp. 8o, 87-88, 91, 98, 126. 


\section{"White Adventurers Familiar with the Forest"}

By the mid-175os Gorham's Rangers was not the company it had once been. Its numbers fluctuated greatly-ranging between fifty and one hundred twenty-five. In addition, the composition of the unit's rank and file shifted from all Indians in 1744 to a multiracial unit in which whites held the majority by 1762 , with Indian participation dipping to as low as 5 percent. In a 1749 petition to the Massachusetts legislature, John Gorham mused over the high rate of attrition suffered by his original Indian unit. The company "was reduced by being taken Prisoner, kill'd, Drowned, and Carried off by the fatigues of that hard and Dangerous service, That there is not one Quarter of said Company now surviving." The number of Indians shrank further during the unit's second deployment, yet there were still enough Native Americans in the company that in August 1749 Gorham was referred to by a government functionary in Halifax as the "Indian Coll[onel]" and as "Coll. Gorham who Commands the Indian Rangers in our service." Still, during that period the proportion of Indian privates in Gorham's Rangers dropped from 75 percent in late 1746 , to 60 percent in early 1748 , to just 28 percent by early 1750 . Most new recruits were Anglo-Americans, trained in ranger techniques by Gorham or the other officers. However, despite its evolving makeup, in the first half of the $175 \mathrm{os}$, periodic reinfusions of Indian men assured that Native Americans remained a core element of the company. 45

\footnotetext{
45Petition of John Gorham. Gorham's 1746 muster list shows only twenty-two Indian privates in the rangers and the company down to forty-two men total. For the functionary who called him the "Indian colonel," see Expeditions of Honour, p. 141. Gorham refers to sending recruiters to Barnstable County, the company's primary recruiting area (Gorham to Melatiah Bourne, 13 December 1748, John Gorham Papers). Records showing the composition of the rangers and related units are: undated (ca. 1746) muster roll of Gorham's Rangers; Joseph Gorham, "Return of Troops"; "Names officers \& men on Comd when took 3 frenchmen." See also "Lt. Colonel John Gorham's Regiment"; Hudson, "Louisbourg Soldiers," pp. 6o-62; Charles Lawrence to John Winslow, 23 September 1755, and Henry Dobson to John Winslow, 22 September 1755, "Journal of Colonel John Winslow of the Provincial Troops, While Engaged in Removing the Acadian French Inhabitants from Grand Pre . . . in the Autumn of the Year 1755," Collections of the Nova Scotia Historical Society, vol. 3 (1883), pp. 71196. For Danks's Rangers, see "A Roll of the Ranging Company at Fort Cumberland,"
} 
Also gone by 1750 were the Indian veterans who had been so vital to the company's early success. Peter Dogamus had languished in a Huron village near Quebec before, his fighting days over, he was redeemed. Veteran ranger Caleb Popmonet, from a leading Mashpee Wampanoag family, was captured with Dogamus but later managed to escape. He never returned to the company. Corporal Jeremiah Queach had apparently had enough of war after 1746; he chose not to reenlist. Joseph Ralph, the whaleboat commander, died in 1749. The most significant loss occurred in the spring of $175^{\circ}$. Captain Sam, already disgruntled that his daughter was detained in service to a Massachusetts household, grew disillusioned that the promises made to him and the other Pigwacket members were still unfulfilled. After seven years of loyal service, the highly valued guide, translator, and negotiator deserted. He led his people back to Maine to live among a related Abenaki band. Then, with his young daughter and others in tow, he removed to the Jesuit mission at Saint Francis. ${ }^{46}$ Gone too was the company's founder and namesake, John Gorham. In 1751, having contracted smallpox, he died in England.

The company's anglicization accelerated when it came under imperial control in 1748. Although company muster rolls do not survive for the period after 1750 , other records suggest that New England Indians continued to serve in Gorham's Rangers while at the same time men from throughout the British Empire and larger Atlantic World were replacing many of the unit's Yankee members. The names of Scotsmen, Irishmen, andthe very people the rangers had been sent to displace-even Frenchmen predominated. British-born career army officers now recruited enlistees not at Cape Cod but at Halifax, Boston,

\footnotetext{
4 August 1758, French and Indian War Collection, American Antiquarian Society (AAS), Worcester, Mass.; and "A List of Capt. Benoni Danks Company of Rangers at Fort Cumberland," 20 February 1761, Massachusetts Collection, AAS. Danks's company seems to have never contained more than a dozen or so Indians total.

${ }^{46}$ Joseph Gorham, "Return of Troops." Popmonet, along with fifty-five other Mashpee Indians, signed a 1753 petition to the Massachusetts government (Mass. Archives, 32:427). The Pigwackets later lived among the Arosaguntacook (Androscoggin) (Documentary History of the State of Maine, 12:60, 71-74).
} 
New London, or New York. Typical of these new recruits was Cornelius Cavanaugh, an Irish immigrant who came to North America with the British army in 1740. Living a transient existence over the next two decades, he married and enlisted in the armed forces twice, doing garrison duty in Maine and serving a spell in Gorham's ranger corps in the 175 os. ${ }^{47}$

Few of the new Indian recruits were Wampanoags, as most of the original members had been, but were from other tribes in southern New England. Jonathan Babesuck and John Womsquam, Christian Nipmuc Indians from Natick, had served under the Gorhams in the Seventh Massachusetts Regiment at Louisbourg. They joined the ranger company after 1746 . Babesuck died while enlisted several years later. Abraham Speen, a Natick leader, was a member of the unit in 1747 and 1748. A Mohegan from Connecticut referred to only as Jaquish was in Nova Scotia with the rangers in 1755 . Later that same year, fourteen Indians, including Mohegans, Pequots, and Niantics from Connecticut, as well as Wampanoags, were transferred to Gorham's company from the Fiftieth Regiment, one of only two British army regiments raised in New England during the war. As late as 1761, unit officers were still culling Indians from provincial regiments. That year, Captain Ebenezer Marrow pulled two Wampanoag veterans, Thomas Tockanot and Eliakim Nehoman, out of their Massachusetts regiment and transferred them to the rangers. Similar to other Indians in Gorham's Rangers, Tockanot, from Martha's Vineyard, was a twenty-seven-year-old experienced whaleman who had served previously in the provincial army. Presumably the rangers did not suit him, for he deserted almost immediately. Four others accompanied him. One was Peter Washanks, a twenty-four-year-old Wampanoag from Rhode Island and likewise a provincial veteran. He was also the grandson and namesake-and thus literally heir-of one of the war captains who had led Benjamin Church's first Indian company during

${ }^{47}$ Cornelius Cavenaugh memorial to William Shirley, 6 January 1755, Mass. Archives, 74:313. Another individual typical of later recruits was John Hall, a twentyyear-old mariner and recent immigrant from Ireland (Boston Evening Post, 29 September 1760). 
King Philip's War. The other three deserters reflected more recent changes to the company: two were newly arrived Irish immigrants; one was an Anglo-American who had been born in Nova Scotia. ${ }^{8}$

By the mid-175os the company's diverse assemblage of individuals reflected the ethnic and racial mix of the British Atlantic: members of various Indian tribes-some of mixed African and Native ancestry, several identified as negroesalong with various Irish, English, and Scots recruits from Europe as well as Acadians and New England Yankees. This diversity made it difficult for observers, both European and Native, to categorize the unit. For example, a report of intelligence gathered by French-allied Native scouts and intercepted by Rogers's Rangers in 1755 described Gorham's Rangers as the "bad subjects" or riffraff of the colonies and as "white adventurers familiar with the forest." The account mistakenly identified the Native American members as Stockbridge Mohicans who, they also erroneously noted, had replaced the earlier "Mohawks." Perhaps two hundred Native Americans from southern New England cycled through the company over its nineteenyear existence, but the vast majority were Wampanoag; no Mohicans or Iroquois are present in any record relating to Gorham's Rangers. Inaccurate observations such as these, coupled with popular stereotypes, have opened a space for some wildly speculative characterizations. A case in point is an oftcited 1954 article by George T. Bates, found in the Collections of the Nova Scotia Historical Society, which describes Gorham's

\footnotetext{
${ }^{48}$ For Babesuck (misspelled "Bathersick") and Womsquam, see "Names officers \& men on Comd when took 3 frenchmen," and "Part of Three Companies All At Present Under the Col's Command and Doe Duty in Town," 20 November 1745, Pepperell Papers; "Journal of Colonel John Winslow," pp. 192-93. For Speen, see Gorham, "Return of Troops, Rangers from Nova Scotia." For Jaquish, see "The Petition of the Selectmen of Worcester," 1 July 1756, Massachusetts Collection, AAS. Tockanot served as an indentured whaleman for Cornelius Bassett in 1755 and was in Captain Jeremiah Mayhew's company stationed in Nova Scotia in 1759. Nehoman was an experienced soldier, first serving in Captain Zacheus Mayhew's company in $175^{8}$ and then as a corporal in Captain Jeremiah Mayhew's company in 1759, before he enlisted in the provincial service again in $\mathbf{1 7 6 1}$ and was exchanged for a white soldier and, like Tockanot, wound up in Gorham's Rangers (Mass. Archives, 33:269-73, 366; 97:140, $277,279,470-71)$.
} 
Rangers as "mostly full-blooded, practically naked Mohawk Indians, with a sprinkling of half-clad half-bloods." They were "devils incarnate," according to Bates, "harrowing and hairraising" to the sedate and lily-white English men, women, and children penned up with them inside Fort Anne in the 1740s. Such prejudiced nonsense has colored historical scholarship about Gorham's Rangers down to the present day. 49

In truth, however, race did matter to those who commanded the rangers, for they believed that Indians were racially predisposed to military service. When the younger Gorham assumed command in 1753 , he redoubled efforts to enlist Native Americans. In $1755^{-56}$, he exchanged white rangers from his company for Indian men culled from different New England provincial and British imperial units stationed in Nova Scotia. Noting "that Service [ranging] Can Never be so well performed by any as by real Indians," Charles Lawrence, the British governor of Nova Scotia, backed Gorham's policy. The rangers were renowned for their long-range mobility and their expertise in reconnaissance. But they were also notorious for driving Acadians and Mi'kmaq from their homes, taking hostages, and destroying crops, settlements, and farms. These were the "Perticular Designs" for which Gorham claimed Indians were so "usefull"; this was the kind of work for which Lawrence felt "real Indians" were best suited..$^{\circ}$ Yet Gorham's

\footnotetext{
${ }^{49}$ George T. Bates, "John Gorham 1709-1751, an Outline of His Activities in Nova Scotia 1744-1751," Collections of the Nova Scotia Historical Society, vol. 30 (1954), p. 29.

${ }^{5}$ For Anglo-American soldiers disturbed by the brutality of both enemy and allied Indians, see "Diary of Jabez Fitch," Mayflower Descendant 10 (1908): 187; Mayflower Descendant 5 (1903): 242; Way, "The Cutting Edge of Culture," pp. 124, 131-38; Correspondence of William Shirley, 2:466, 553; Papers Relating to the Forcible Removal, p. 157. Communications between William Shirley and officers in Nova Scotia during the Acadian Removal clearly reveal this perceived racial preference (John Gorham to John Winslow, 22 September 1755, in "Journal of Colonel John Winslow," pp. 71-196; Charles Lawrence to John Winslow, 23 September 1755, and Henry Dobson to John Winslow, 22 September 1755, in "Journal of Colonel John Winslow of the provincial troops, while engaged in the siege of Fort Beausejour, in the summer and autumn of 1755 ..., "Collections of the Nova Scotia Historical Society, vol. 4 [1885], pp. 113-246; Plank, An Unsettled Conquest, pp. 49-5o, 69, 71, 79, 82). The British were not above using Indians to induce the same fear that French-sponsored Indian raids induced in English settler populations (Peter Silver, Our Savage Neighbors: How Indian War Transformed Early America [New York: W. W. Norton, 2008]).
} 
ranger corps was still assigned these "savage" tasks long after Native Americans had dwindled to a small minority within the company. Later, British observers could not fathom why white colonial rangers behaved so "savagely." Only by understanding the evolution of Gorham's Rangers from an Indian unit-expected to carry out "savage" acts because they were Indians - to a predominantly Anglo-American one, still carrying out the same acts of violence, can these responses be properly understood.

In 1747 John Gorham traveled to England and convinced the British high command that his rangers should become an independent company in the British army. Thereafter, between 1749 and $\mathbf{1 7 5 1}$, leaders in Nova Scotia created an entire ranger corps, consisting of at least seven companies, all modeled on Gorham's unit although staffed by Anglo-Americans. In 1749, an advertisement pitched to potential recruits noted that the new companies would "traverse the woods in pursuit of the Indians, in the same manner that Col. Gorham does with his rangers"; another from 1751 announced that a new military contingent would be established "in the same manner as Captain Gorham's company of Rangers." Thus did the tactics pioneered by the company's original Indian rangers, then taught to the Gorhams and other Anglo-American members of the company, become widely disseminated among British and provincial troops in the northeastern borderlands-five years before Rogers's Rangers were formed. ${ }^{51}$

\section{"A Singular Mark of the Most Unheard-of Cruelty"}

Paul Mascerene, General James Wolfe, and, especially, Lord Jeffery Amherst, the commander of British forces in North America during the second half of the Seven Years War, all

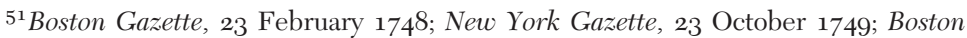
Post-Boy, 27 May 1751. They were led, in turn, by Captain Francis Bartelo, Major George Scott, Captain (and later Major) Joseph Gorham, Captain Charles Proctor and, from New England, Major Ezekiel Gilman, Captain William Clapham, and Captain Benoni Danks. Scott in particular went on to organize and lead British light infantry units (Beamish Murdoch, History of Nova Scotia, or Acadie, vol. 2 [Halifax, 1866], pp. 162-63, 19o; Expeditions of Honour, pp. 82-86). 
despised Indians but tolerated them as rangers because, the authorities believed, they terrified enemy Indians and Canadians more effectively than did white soldiers. Although primary sources written by Mi'kmaqs and Acadians are extremely rare, their impressions can be gleaned from the writings of French missionaries like Le Loutre, mentioned earlier, and Abbé Pierre Maillard (1710-62). In his polemic against British expansionism, An Account of the Customs and Manners of the Mickmakis and Maricheets, Savage Nations, Now Dependant on the Government at Cape Breton (1758), Maillard recounted an episode that took place during a French retreat from Annapolis Royal in 1744 :

... towards the end of October, Mr. Gorrhon [Gorham] commanding a detachment of English troops, sent to observe the retreat of the French and savages were making from before Port Royal in Acadia: This detachment having found two huts of the Mickmaki-savages, in a remote corner, in which there were five women and three children (two of the women being big with child), ransacked, pillaged and burnt the two huts, and massacred the five women and three children. It is to be observed, that the two pregnant women were found with their bellies ripped open. An action which those savages cannot forget, especially as at that time they made fair war with the English. They have always looked on this deed as a singular mark of the most unheard-of cruelty. $5^{2}$

Indeed, the incident was one sticking point in the protracted dispute over unpaid scalp bounties. Although the facts are not in contention - the rangers did kill noncombatants outside Annapolis Royal in 1744-Maillard's propagandist critique embellishes them to convey the Mi'kmaqs' ostensible ire. The image of the unborn child ripped from its mother's womb is designed to provoke an extreme reaction and, since ancient times, has served to discredit one's enemy as dishonorable and uncivilized. During the war, British settlers frequently accused French-allied Indians of the outrage; most charges were

$5^{2}$ Pierre Maillard, An Account of the Customs and Manners of the Mickmakis and Maricheets, Savage Nations, Now Dependant on the Government at Cape Breton (London, 1758), pp. 62-63. 
subsequently proven to be false. In any case, whether Maillard's report of the incident is true or distorted for effect, Indians in Nova Scotia cited it years later when calling for revenge. Their hatred of English invaders openly celebrated in their rituals, the Mi'kmaq were soon routinely torturing and executing English prisoners. Violence begat violence. British officials in Nova Scotia's Governor's Council, of which John Gorham was a member, offered bounties for Mi'kmaq scalps along with "premiums for dead Indians" as high as £1o sterling. No longer simply a military strategy, imperial violence in the Maritimes during the 174 os and 175 os began to take on the appearance of ethnic cleansing, a war intended to remove or exterminate a population rather than merely defeat an opposing army. ${ }^{53}$

The enmity the rangers inspired was described by William Pote, captain of one of the provincial supply vessels captured in 1745 along with the Indian rangers at Annapolis Royal. During the trek to Quebec, Pote kept a journal in which he recorded that several Indian rangers were beaten, tortured, and killed by Mi'kmaq hoping to assuage their grief for the loved ones the rangers had murdered. Still, the types of torture and abuse Pote describes were not at all uncommon on the frontier and during this era. Less common was the hatred the Mi'kmaq felt toward the company's leader, John Gorham, whom Mi'kmaq snipers tried to assassinate several times. ${ }^{54}$

53The use of this image has a long history (Silver, Our Savage Neighbors, pp. 8185, 169-70; Papers Relating to the Forcible Removal, p. 149). Shortly after the siege of Louisbourg in 1745, another incident further fueled Mi'kmaq resentment: New England soldiers desecrated a Catholic Mi'kmaq burial ground near Port Toulouse on Cape Breton Island (The Old Man Told Us: Excerpts from Mi'Kmaw History, 150o1950, ed. Ruth Holmes Whitehead [Halifax: Nimbus Publishing, 1991], pp. 110-11, 115). Ethnic cleansing is defined by the United Nations as "a purposeful policy designed by one ethnic or religious group to remove by violent and terror-inspiring means the civilian population of another ethnic or religious group from certain geographic areas" (United Nations Security Council, "Final Report of the Commission of Experts Established Pursuant to Security Council Resolution 78o [1992]," http://www.un.org; Andrew Bell-Fialkoff, "A Brief History of Ethnic Cleansing," Foreign Affairs 72 [1993]: 110).

${ }^{54}$ The Journal of Captain William Pote, pp. 59-6o, 62-63, 86. See Daniel K. Richter, The Ordeal of the Longhouse: The Peoples of the Iroquois League in the Era of European Colonization (Chapel Hill: University of North Carolina Press, 1992), pp. 3238, 144-49, 233-34. Wayne Lee (Barbarians and Brothers: Anglo-American Warfare, 
John Knox, an Irish officer in the British garrison at Fort Cumberland, on the Chignecto Peninsula, witnessed a chilling event in January 1759. When a company of rangers, Captain Benoni Danks's men, were sent out to "scour the country" for several rangers and a number of regulars who had disappeared, they discovered that the four regulars had been partially stripped, scalped while alive, and then shot. The Mi'kmaq attack was probably orchestrated by Abbé Maillard, who, since the capture of Le Loutre in 1755 , was coordinating what was left of the crumbling Acadian-Mi'kmaq resistance to the British. Whether or not the one ranger's body found was a New England Indian is not mentioned, although according to a $175^{8}$ muster list, Danks's company contained at least five Natives. In any case, he had not been shot; the skin on his head had been "flayed" and his entire scalp removed, then he was bludgeoned to death. Thereafter the unfortunate ranger's corpse had been carefully mutilated; a "great deliberation was used in this barbarous dirty work," Knox commented. The soldiers at the fort told Knox that they had seen such handicraft before; it was a special ceremonial treatment reserved for rangers who fell into Mi'kmaq hands. ${ }^{55}$

In a final sign to their enemies, the Mi'kmaq warriors covered the body with writing. As Knox described, "the ranger's body was all marked with a stick and blood in heiroglypic [sic] characters." The writing on the ranger's corpse, indecipherable to English observers but intelligible to Mi'kmaq observers, was komquejwi'kasikl—a combination of pictographs,

1500-1865 [New York: Oxford University Press, 2011]) speculates that Indians' ability to focus their vengeance on the actual perpetrators often led to more restrained treatment of other prisoners (pp. ${ }^{15} 5^{-58}, 163^{-64}$ ). The Mi'kmaq only managed to wound Gorham seriously once, in April 1750, when, near Pizquid, a party of Indians ambushed the rangers. A doctor's detailed account of treating the terrible leg wound he received was published in the press (Boston News-Letter, 15 September 1748 and 28 June 1750; New York Gazette, 16 April 1750).

${ }^{55} \mathrm{Knox}$, Historical Journal, 1:288-91. This is no doubt a reference to an incident, reported in the Boston Weekly News on 18 August 1757, surrounding the capture of a thirty-man detachment of rangers outside Fort Cumberland on 1 July 1757. The report included descriptions of the grisly mutilations (French and Indian War Notices Abstracted from Colonial Newspapers, vol. 2: 1756-1757, ed. Armand Francis Lucier [Lanham, Md.: Heritage Books, 2007], p. 276); "A Roll of the Ranging Company at Fort Cumberland." 
mnemonic devices, and symbols — an independently created indigenous script, which anthropologists argue predates European contact. Catholic missionaries quickly saw the value of komquejwi'kasikl, most often employed in reciting prayers, as a tool for spreading Christianity, and they encouraged its use. The Mi'kmaq having converted to Catholicism in the seventeenth century, French warrior-priests like Le Loutre, Maillard, and others fanned anti-Protestant sentiment among the Indians, which in the 1740 os the missionaries in turn used to promote Mi'kmaq violence against the British, a deal they sweetened with an offer to pay bounties for English scalps. The Mi'kmaq did not need such elaborate incentives. Hunter-warriors long before the French arrived, they were a proud people who possessed a keen sense of justice and retribution. Ill treatment of Mi'kmaqs was met with swift reprisal, as were attacks on Mi'kmaq independence..$^{6}$

The ritualistic despoliation of the ranger's body is open to a number of interpretations. It may simply have been a sign of Mi'kmaq contempt for their defeated enemy. However, the hieroglyphs, usually reserved for sacred writings, may have marked the rangers as spiritual Others - the true savages; devils incarnate; enemies of France, of the Catholic Church, and of God. Perhaps the komquejwi'kasikl signaled that the Mi'kmaq were engaged in a Holy War. Three months later British troops found the remains of the other missing regulars and rangers. They too had been "cut and mangled in the most shocking manner." 57

${ }^{56}$ David Schmidt and Murdena Marshall (Mi'Kmaq Hieroglyphic Prayers: Readings in North America's First Indigenous Script [Halifax: Nimbus Publishing, 1995]) found that the hieroglyphs were not only used in sacred worship but also sometimes for sending messages. Knox, Historical Journal, 1:89-9o; Prins, The Mi'Kmaq, pp. 118-22, 131, 136-37. Many British colonial soldiers also saw the larger geopolitical contest between England and France as fundamentally a religious struggle between Protestantism and Catholicism (see Anderson, A People's Army, pp. 196-223, and Ann M. Little, Abraham in Arms: War and Gender in Colonial New England [Philadelphia: University of Pennsylvania Press, 2007], pp. 166-204).

${ }^{57}$ French and Indian War Notices, 3:233. Thanks to Harald E. L. Prins, of Kansas State University, for advice on interpreting komquejwi'kasikl. Prins, The Mi'Kmaq, pp. 85-87, 133-52; Erik R. Seeman, Death in the New World: Cross-Cultural Encounters, 1492-1800 (Philadelphia: University of Pennsylvania Press, 2010), pp. 55-57, 92-94, 176-77, 273-74; Knox, Historical Journal, 1:288-91; Finn, "Le Loutre, Jean-Louis"; and Micheline D. Johnson, "Maillard, Pierre," Canadian Biography Online. 
The Mi'kmaq revenge killings testify dramatically to the fear and loathing directed toward Gorham's Rangers and its sister unit under Captain Danks. Almost inevitably, such deep emotions had a lasting impact on the reputation of the British ranger corps in Nova Scotia. Some settlers characterized Danks's company as "a merciless soldiery" and "bloody hounds" and their actions as "barbarous proceedings." The British regulars alongside whom the rangers sometimes served were shocked by their cruel ways. In April 1758, during a mission to remove recalcitrant Acadians from settlements lining the Petitcodiac River on the Bay of Fundy, tensions flared between regulars and rangers over the treatment of an Acadian woman. Lieutenant Knox recorded his eyewitness account of this event as well: "One of the French women, seeing her children seized by a ranger, knocked him down, which another resenting, grasped his tomahock (or small hatchet) and would instantly have laid her head open, had not he been prevented by a regular Officer." ${ }^{8}$

The barbarity of American frontier warfare was especially abhorrent to British officers and soldiers during the siege of Quebec. Enraged when Indians and Canadians scalped Englishmen they had captured, James Wolfe, the British commanding general, issued angry manifestoes threatening devastating reprisals if the practice continued. Despite his indignation, Wolfe failed to prevent his own troops from committing similar "barbarities" against Canadians and Indians. Wolfe wrote his first protest just days after Gorham's men scalped the nine Indians on Île d'Orléans. Lieutenant Malcolm Fraser of the Seventy-eighth Regiment noted in disgust that a party of rangers sent to take prisoners and gather intelligence about French defenses killed two young children they had captured. When recalling the incident, Fraser launched into a tirade against American frontier warfare. The children were, according to him,

in a most inhuman manner murdered by these worse than savage Rangers, for fear, as they pretend, they should be discovered by the 56.

${ }^{8}$ Papers Relating to the Forcible Removal, p. 141; Knox, Historical Journal, 1:155- 
noise of the children. I wish this story were not fact, but I am afraid there is little reason to doubt it - the wretches having boasted of it on their return ... this barbarous action proceeded from the cowardice and barbarity which seems so natural to a native of America, whether Indian or European extraction.

Fraser clearly had little stomach for killing noncombatants, although the highland regiments in which he served notoriously gave no quarter on the battlefield, and some regulars took scalps during the campaign. The rangers, of course, especially Gorham's company, had a track record of killing and scalping civilians as a way of terrorizing enemy populations in order to force them to submit to British rule; moreover, this combined company of Anglo-Americans and Indians scalped noncombatants of all ethnic backgrounds. What was appalling for the Europeans was simply business as usual along the American frontier. 59

\section{"Ventured My Life in Defense of the English People"}

Serving in the military during the colonial wars offered New England's Indian men not only a means of proving themselves in accord with their culture's hunter-warrior definitions of masculinity but also short-term economic benefitswages, debt relief, and access to trade goods-for themselves

59 "Memoirs of the Siege of Quebec and Total Reduction of Canada in 1759 and 1760 by John Johnson, Clerk and Quarter Mas'r Sergeant to the 58th Reg't," in A. Doughty, The Siege of Quebec and the Battle of the Plains of Abraham, 6 vols. (Quebec: Dussault and Proulx, 1901-2), 5:80. For the extended quote by Fraser, see Extract from a Manuscript Journal, Relating to the Siege of Quebec in 1759, kept by Colonel Malcolm Fraser, Then Lieutenant of the 78th (Fraser's Highlanders) (Quebec, 1866), pp. 6-7. See also Way, "The Cutting Edge of Culture," pp. 131-35; Ian M. McCulloch and Timothy J. Todish, British Light Infantryman of the Seven Years' War: North America 1757-1763 (London: Osprey Publishing, 2004), pp. 4-11; George A. Bray, "Major Scott's Provisional Light Infantry Battalion," Early America Review 1 (1996), online at http://www.earlyamerica.com/review/winterg6/; Colin G. Calloway, White People, Indians, and Highlanders: Tribal People and Colonial Encounters in Scotland and America (New York: Oxford University Press, 20o8); Geoffrey Plank, "New England Soldiers in the St. John River Valley, 1758-176o," in New England and the Maritime Provinces: Connections and Comparisons, ed. Stephan J. Hornsby and John G. Reid (Montreal: McGill-Queens University Press, 2005), pp. 68-69. 
and their families. But by the early 1760 , the costs of repeated deployments - death, disease, injury, and captivityoutweighed any advantages of soldiering. In 1749, Gorham noted that during the company's first three years, threequarters of the Indians in the rangers were killed or captured, an incredibly high casualty rate for this or any era.

The rangers' commander reminded Massachusetts authorities that such devastation "impoverishes that county [Barnstable] in this Province where said Company was raised," imposing on it "a burthen ... of Widows and Children of the Deceased and those in Captivity." Gorham did not exaggerate. The fifty to sixty Wampanoag and Nauset men initially recruited for the company in 1744 comprised over half of the able-bodied Indian men in Barnstable County. ${ }^{60}$ The small population clusters at Mattakesett ("Indiantown" in Yarmouth), Potanomacut (in Harwich), and Nauset (in Eastham) were devastated by the wartime casualties. In a joint petition written toward the end of the French and Indian War, village leaders explained that "Many of our nation have entered into ye war with the English against ye French and Indian[s] in alliance with them[,] and many of them have Died in ye service \& left ye squas \&

\footnotetext{
${ }^{60} \mathrm{My}$ calculation is based on the populations of Barnstable County's Indian reservations and enclaves circa $175^{\circ}$. The six largest communities contained around 595 individuals (Mashpee 26o; Herring Pond 115; Potanomacut 8o; Yarmouth 6o; Chatham 30 ; and Harwich 50), with another 110 individuals living in small clusters or individual households in Falmouth, Barnstable, and elsewhere, for a total of 705 individuals. Because women historically outnumbered men in Native communities and due to other demographics relating to age, we can assume that no more than 15 percent of the population (or 106 individuals) was fit for military service. Gorham enlisted approximately fifty-five Wampanoag and Nauset men from Barnstable County for the initial company in 1744, or half of all those available. My estimates are based on various population counts by missionaries or Anglo-American observers. See Elisha Tupper, "Herring Pond Indians, 1757," MHS, Misc. Bound Manuscripts, August 1757; Extracts from the Itineraries and other miscellanies of Ezra Stiles, D.D., LL.D, 1755-1794 . . ., ed. Franklin Dexter Bowditch (New Haven: Yale University Press, 1916), pp. 162, 165, 167-70; anon., "Report of a Committee on the State of the Indians in Mashpee and Parts Adjacent [in 1767]," Massachusetts Historical Society Collections, 2d ser. 3 (1815), pp. 12-17; "The Number of Indians Belonging to the Potenomacut Chh[urch]," MHS, Misc. Bound Manuscripts, December 1765; entry for 19 July 1758, Gideon Hawley, Diary, MHS; and Collections of the Massachusetts Historical Society, 1st ser. 10 (1809): $112-15,129-36$. On Indian women outnumbering Indian men historically, see Patricia Rubertone, Grave Undertaking: The Archaeology of Roger Williams and the Narragansett Indians (Washington, D.C.: Smithsonian Institution Press, 2001), pp. 161-64.
} 
children in distressing circumstances." Others returned home wounded and disabled, but there were no resources to ease their plight. In some instances, overseers sold reservation lands to pay for the support of these needy families and veterans, which accelerated the problem of land loss and the fractionalization of reservation holdings. ${ }^{61}$

Few of southern New England's Indian communities remained untouched by the colonial wars. Native women had long outnumbered men, but now the demographic imbalance became acute, and they were forced to look outside their communities for husbands. Marriage between whites and nonwhites in the region was not only illegal but discouraged by custom, and so Indian women increasingly turned to enslaved and free African males. This pattern of exogamous marriage became the norm in the next generation. These unions produced mixedrace offspring that whites referred to as "mustee" or "mulatto" (although the two terms were often used interchangeably, the former designation was generally reserved for individuals of mixed African and Native ancestry and the latter typically applied to people of mixed European and African ancestry). After the Revolution, especially, when these mixed-race individuals grew into adulthood, they were no longer deemed "real" Indians; instead, whites categorized them as "blacks" and associated them with their African ancestry, frequently denying their

\footnotetext{
${ }^{61}$ Participation in the wars ravaged Natick, just outside of Boston. Jean O'Brien identified almost thirty Natick Indians who served in the military in King George's War and the Seven Years War (some in Gorham's Rangers). Many died from disease contracted in the military. In $175^{8}$, Indian soldiers returning to Mashpee infected their community as well. O'Brien, Dispossession by Degrees, pp. 142-48, 150, 156-62, 212-15; Mandell, Behind the Frontier, pp. 118, 128-29; Stephen Badger, "Historical and Characteristic Traits of the American Indians in General, and those of Natick in Particular," Collections of the Massachusetts Historical Society for the Year $179^{8}$ (1798), pp. 40-41. The gender imbalance created by losses in the colonial wars is a phenomenon long noted. See Jack Campisi, The Mashpee Indians: Tribe on Trial (Ithaca: Syracuse University Press, 1991), pp. 87-89; Hutchins, Mashpee, pp. 79-88; Den Ouden, Beyond Conquest, pp. 30-38; and esp. Mandell, Tribe, Race, History, pp. 39-40, 42-59. For the impact on Cape Indian communities, see Petition of Isaac James et al., 19 November 1757, Mass. Archives, 33:10. The severe losses Gorham noted in his petition compare to some of the worst casualty rates reported during the Seven Years War (Fred Anderson, Crucible of War: The Seven Years' War and the Fate of Empire in British North America, 1754-1766 [New York: Vintage Books, 200o], pp. $105,240,244-47,337,501$ ).
} 
Native heritage altogether. As such, whites felt that these individuals were not entitled to status as tribal members and so perceived tribal rolls as shrinking. Further, the growing number of mixed-race individuals exacerbated (or sometimes created) internal divisions within tribes. As the number of "pure-bloods" dwindled and with mixed-race Indians often denied status as tribal members, whites questioned tribal sovereignty, which led to lands becoming more vulnerable to seizure, and resulted in some reservations being broken up and sold off in a final act of dispossession. Declining numbers of Indian men, frequent intermarriage between blacks and Indians, and the increasingly mixed-race character of New England tribes after the colonial wars were taken by whites to be evidence of what they wanted to see: Indian degeneracy and disappearance. Reports of Indian men's courageous service in the colonial wars of the northeast were quickly forgotten, replaced by a narrative of Anglo-American conquest and the marginalization of ostensibly inferior indigenous peoples, who had no place in the emerging nation. ${ }^{62}$

More than twenty-five years ago, Fred Anderson argued in A People's Army: Massachusetts Soldiers and Society in the Seven Years' War that service in the imperial wars shaped the identity of white New Englanders not only as citizens of the empire but, more important, as Americans, who were different from the English alongside whom they fought. Peter Silver has asserted, on the contrary, that the terror of colonial frontier warfare, in which Indians played such a significant role, tended to collapse distinctions among Europeans and solidified a "white" racial identity as well as strengthened a

\footnotetext{
${ }^{62}$ Mandell, Tribe, Race, History, pp. 22, 24, 35-59, 67, 167-83, 197-201, and "Shifting Boundaries of Race and Ethnicity: Indian-Black Intermarriage in Southern New England, 1760-1880," Journal of American History 85 (1998): 466-501; Ruth Wallis Herndon and Ella Wilcox Sekatau, "The Right to a Name: Narragansett People and Rhode Island Officials in the Revolutionary Era," in American Encounters: Natives and Newcomers from European Contact to Indian Removal, 1500-185o, ed. Peter C. Mancall and James Hart Merrell (New York: Routledge, 200o), pp. 437-39; Jack D. Forbes, Africans and Native Americans: The Language of Race and the Evolution of Red-Black Peoples (Urbana: University of Illinois Press, 1993), pp. 215-17; O'Brien, Dispossession by Degrees, pp. 146, 201-3, 214.
} 
commitment to representative government. In light of these arguments, one might ask how forays into the contested northeastern borderlands shaped Indian soldiers' identity vis-à-vis provincial whites as well as the British troops with whom they served. The reflections of one veteran of Gorham's Rangers might be a good place to begin such an investigation.

John Simons, a Wampanoag preacher from the Teticut reservation in Middleboro, Massachusetts, served in the provincial forces as well as in Gorham's Rangers, where he was the unofficial chaplain for the unit's Native Americans. In $175^{2}$, he lost his leg in battle, returned home unable to work, and was reduced to penury. As his lands were being seized by creditors, he wrote a bitterly worded petition to the Massachusetts legislature in which he begged for aid, reminding lawmakers that "[I have] five times ventured my life in defense of the English people." ${ }_{3}$ He knew British colonists benefited from his services, yet he clearly did not feel like one of them. Originally motivated to fight for the English as a cultural and economic survival strategy, Simons and his fellow Indian veterans found that their service in the military reinforced their status as a distinct, socially marginal, and expendable minority. Gorham's Indian rangers played a crucial part in conquering territory for the empire and transforming how wars were fought in the northeast even as they were being dispossessed of lands that were rightfully theirs.

${ }^{6}$ Mass. Archives, 32:318, 419-21.

Brian D. Carroll is Assistant Professor of History at Central Washington University, where he teaches courses on early American history. Also an affiliate faculty member of CWU's American Indian Studies program, he is active as well in Pacific Northwest public history. He is currently revising a book manuscript about New England Indians in the British colonial military. 